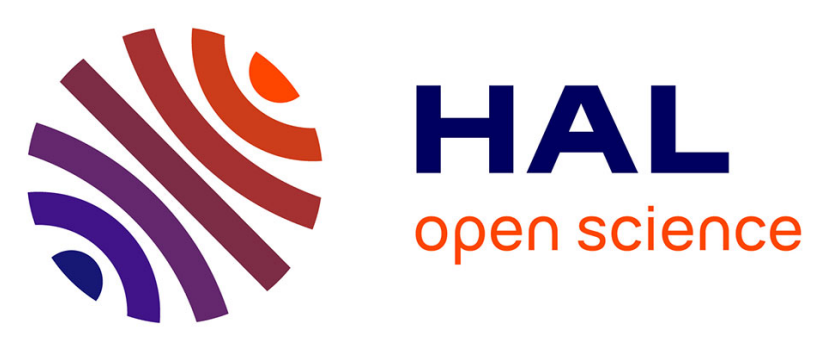

\title{
Coastal cities, port activities and logistic constraints in a socialist developing country: The case of North Korea
}

\author{
César Ducruet, Jin-Cheol Jo
}

\section{To cite this version:}

César Ducruet, Jin-Cheol Jo. Coastal cities, port activities and logistic constraints in a socialist developing country: The case of North Korea. Transport Reviews, 2008, 28 (1), pp.1-25. halshs00458582

\section{HAL Id: halshs-00458582 \\ https://shs.hal.science/halshs-00458582}

Submitted on 21 Feb 2010

HAL is a multi-disciplinary open access archive for the deposit and dissemination of scientific research documents, whether they are published or not. The documents may come from teaching and research institutions in France or abroad, or from public or private research centers.
L'archive ouverte pluridisciplinaire HAL, est destinée au dépôt et à la diffusion de documents scientifiques de niveau recherche, publiés ou non, émanant des établissements d'enseignement et de recherche français ou étrangers, des laboratoires publics ou privés. 


\title{
Coastal cities, port activities and logistic constraints in a socialist
}

\section{developing country: The case of North Korea}

\section{Published in: Transport Reviews 28(1), 1-25}

\section{CÉSAR DUCRUET ${ }^{*}$, Assistant Professor}

Erasmus University, School of Economics, Faculty of Economic Sciences

P.O. Box 1738, 3000 DR Rotterdam, The Netherlands

Tel. +31 (0) 10-408-1678 / Fax +31 (0) 10-408-9141 / Email: ducruet@ few.eur.nl

\section{JiN CHEOL Jo, Research Fellow}

Korea Research Institute for Human Settlements (KRIHS)

1591-6 Gwanyang-dong, Dongan-gu, Anyang-si, Gyeonggi-do 431-712 Republic of Korea

Tel. +82 (0) 31-380-0164 / Fax +82 (0) 31-380-0482 / Email: jincjo@krihs.re.kr

\begin{abstract}
This paper analyses the interplay of transport and development in North Korea, one of the most state-controlled and underdeveloped countries of the world. While broader aspects have been well described by various studies, logistics have been given little attention as permissive or restrictive factors in the country's development. Despite the recent reforms and the growth of trade, the development of North Korea is confronted to the weaknesses of the transport system and inland logistics. An analysis of vessel movements at North Korean ports (19852006) shows that although coastal economies may increasingly use maritime transport to overcome inland blockages, the evolution of port traffics better reflects broader trends such as general economic decline, westward shift of populations, and the polarization of economic
\end{abstract}

\footnotetext{
* Corresponding author
} 
activities around Pyongyang area. Beside those trends, the research also estimates the importance of maritime transport in North Korean trade and it provides a base upon which further studies can be conducted, so as to better evaluate the place of North Korea among transport studies.

Keywords: DPRK, North Korea, Port city, Socialist Developing Country, Transition

\section{Acknowledgements}

Authors would like to thank Mr. Stanislas Roussin, General Manager at Korea Strategic Data (KSD, Seoul) and Graduated in Geo-Economics (Le Havre University, France) for his useful comments. 


\section{Introduction}

Following the crisis of the 1990s, provoked by the collapse of socialist countries and accentuated by natural disasters, Kim Jeong Il's military-oriented government has favoured a number of measures for the Democratic People's Republic of Korea (DPRK, hereafter North Korea)'s economic and social improvement. This radical break from the country's past attitude toward the outside world is based on institutional reforms, territorial management and increased relationships with other countries. Moreover, the ongoing changes are making transportation and logistics breathtakingly important, given the strategic location of North Korea within Northeast Asia and its potential for the processing and exportation of both raw material and manufactured goods. Its emerging status as a "transition" economy thus allows comparison to the role of ports and transport activities in such countries (Ledger and Roe, 1996; Thorez, 1998a; Jauernig and Roe, 2000 and 2001; Brodin, 2000). Notably, it is interesting to analyse the North Korean case because of its original identity, between developing and socialist countries, in terms of territorial planning and ideological constraints (Jo and Adler, 2002a).

Although transportation issues have been analysed in the case of transition countries and developing countries, it has never been confronted with the specific case of North Korea, a socialist developing country. Its proximity to major markets like China, South Korea, Japan and Russia gives to North Korea a particular advantage compared to other socialist developing countries like Vietnam and Cuba. Port studies have been 'few and dated' outside developed countries (Airriess, 1989), whereas 'the role of seaports - and indeed of transport facilities in general - as economic enablers and sometimes as stimuli to development is frequently underestimated' (Hoyle and Hilling, 1984). Although North Korea is still far from reaching the development stages of new port construction in Thailand (Robinson, 1981) or the problem related to industrial, port and urban concentration in Africa (Hoyle, 1981), it offers 
an original case for studying the political factors influencing port development as seen in the Polish (Taylor, 1984) and Baltic (Brodin, 2003) cases. Given the limited information about North Korea, this paper adopts a broader view on the links between transport and development in a socialist developing country by refining a number of dispersed information which help to understand the importance of transport among - and in relation with - other issues. The level and nature of port activities are a good indicator of the evolution of the related hinterlands. Thus in this paper, ports in North Korea are seen as windows on internal and external changes rather than enablers of economic development.

One may argue that studying transport and development in an isolated and declining country might not bring anything new to port studies; however, the study of ports in North Korea is based on several arguments. Despite the militarist and unstable attitude of the North Korean regime, foreign investment is growing in North Korea, notably after the reforms. Also, two maritime façades, eight international trading ports in such a small country, and the coastal location of most large cities are advantages in favouring economies of scale for industries. Such argument is also founded on the logistic constraints in moving goods inland. Energy shortages and the dereliction of road and railway infrastructures result in cost and delays for connecting the urban system. Furthermore, it is believed that coastal cities are differently confronted to the country's difficulties.

The first section introduces the methodological problems of the research and the main data sources for studying transport issues in North Korea. The second section offers a descriptive explanation of the recent changes in one of the world's less known countries, in terms of economic reforms, territorial management, trade evolution and industrial development, by using updated data from the most reliable organisations. The third section reviews the different sources for analysing the North Korean transport system as a means to acknowledge the scarcity of data about ports and maritime transportation, and provides an overview of 
logistics issues. The fourth section analyses the main trends in the evolution of North Korean maritime transportation (1985-2005), and develops the comparison between the traditional port-city functions of coastal cities and the evolution of vessel movements. Finally, concluding remarks are given about the relation between institutional reform, technical constraint and transport development in North Korea, for a contribution to the study of ports and logistics as permissive or restricting factors in development (Hoyle, 1974).

\section{Methodological issues}

Throughout the literature about North Korea, transport-related issues have not yet been consistently developed. Moreover, port-related issues in North Korea are not a core subject, because most works deal with land transport and the connection of North Korea to continental networks (e.g., estimations of freight flows by train), except for the Rajin-Seonbong FreeTrade Zone experiment. Although regular announcements can be found in the press about the development of North Korean ports, most projects cannot be verified because of the high level of protectionism since the army controls ports in North Korea.

Thus, this research proposes an overview of the economic situation of the country by synthesising a large part of the existing English-based literature, dispersed through research reports, governmental papers, worldwide directories, newspapers, professional websites, and working papers from various countries and scholars. Korean sources include publications from the South Korean Ministry of Unification, the Bank of Korea, and the Korea Trade Investment Promotion Agency (KOTRA). Non-Korean organizations or researchers, willing to provide estimates about this unknown country in general, provide all other sources. In all cases, figures should be used with caution, as no data comes directly from North Korea itself, and one may even doubt the capacity of the North Korean regime to furnish any coherent information about the country. 
Sea transport statistics on North Korea are limited to the yearly figures of the International Road Transport Union available until 1990 (IRU, 1996), and the estimations and forecasts of the Korea Maritime Institute until 2020 (Kim et al., 1998) on a national scale. The South Korean Ministry of Unification provides some port-based statistics, but it is limited to interKorean shipments. The main source used in this paper allows overcoming such limitations, and it has the advantage of coming from an independent and reliable organisation. Although such data cannot indicate the real amount of cargo loaded and unloaded at the ports, it provides the possibility to compare their activity in terms of ship capacity, along a period of 20 years. Furthermore, it helps to avoid relying on mismatched estimations from published statistics.

The database on vessel movements provides information about the daily arrival and departure of trading vessels above 100 Gross Registered Tons (GRT) together with their Deadweight Tonnage (DWT), container capacity, year of construction, flag, ship owner, origin and destination by foreign port, and many others. The type of ships can be used as a surrogate for the nature of the goods transported. Given the cost of shipping to this country, one can acknowledge that most ships have not been empty when calling at North Korean ports. Another very important argument in favour of this source is that it allows bypassing the army itself for accessing local-based data related to ports. Of course, the data has also important lacks such as the difficulty to:

- distinguish commercial flows and humanitarian aids;

- get a more detailed measure of "bulk" and "general cargo", which represent more than $80 \%$ of cargoes on an average basis, with the other cargoes divided between cement, chemical, container, fish products, reefer, ro-ro, tanker, vehicles, and wood;

- separate import and exports, as the same ships come and go without indicating the amount of cargo loaded and unloaded. 


\section{Changes in North Korea}

\subsection{Economic reforms and territorial management}

In July 2002, reform measures were launched for the entire economy, following the June 15 Joint Declaration with South Korea in 2000 and the announcement of the "new way of thinking' in January 2001. It aimed at adjusting consumer prices, wages and foreign exchange rates, together with expanding the autonomy of businesses to increase flexibility and productivity. Despite its former negative connotation, the concept of market is officially recognized since March 2003 as part of the 'practical socialism' inspired by the Chinese model. This was made possible by a gradual empowerment of the cabinet at the expense of the party's influence. This led to the development of commercial distribution, with an increase in general markets, and shops and stores managed individually and advertised through trademark signs in public places (e.g. Pyeonghwa Automobiles). Factories, farms and private businesses were given greater decision power to buy land and raw materials, to receive loans from banks instead from the state, to hire employees, to profit from the selling of surplus products, and to invest in labour welfare or the facility improvement.

A major planning instrument to open DPRK to the outside world and increase its profits is the free-trade zones and the reorganization of administrative units. Following the Joint Venture Law in 1984, the first Special Economic and Trade Zone was launched in 1991. This act covered the city of Rajin and the district of Seonbong $\left(746 \mathrm{~km}^{2}\right)$, part of the wider Tumen River Economic Zone, a border region with China and Russia created for enhancing the logistic, port and industrial advantages of the area, named Raseon since 2000. The development of Rajin-Seonbong has often been constrained by its remoteness and by the lack of transparency of its management following its creation (Jung et al., 2003). However, with recent Chinese investment, the interest in the region has been growing. Though the Raseon 
Special Economic and Trade Zone had not been successful due to accessibility problem, recent Chinese effort to expand port activity in the Pacific Area has been making this special zone prospective in development.

These three major achievements were made in 2002: the city of Sinuiju with around 50 surrounding local units was designated a Special Administrative Region under the control of the central authority; the Mount Geumgang was chosen as a Tourism District in Gangwon province; and the Gaeseong Industrial District was created close to the ancient capital of the Goryeo Kingdom. Discussions are in progress about the designation of Nampo port and the outlying Wawoo district as a Special District. The Special Administrative Region of Sinuiju, bordering the Chinese city of Dandong along the Amrok River, is a strategic path through which almost $80 \%$ of North Korean exports pass. Its major focus is to reconvert its industrial facilities within a multifunctional district of $130 \mathrm{~km}^{2}$. Though it was not successfully launched due to subtle diplomatic difference between China and North Korea, growing Chinese interests tend to enlarge outer recognition of this region. Chinese government expects some positive effects on Liaoning province while supporting the project with energy. As in RajinSeonbong, the lack of an inland connection from the zone to the capital city has been a major obstacle.

Two other specialized zones concern the specific relationships with South Korea. South Korean players pursuing balanced growth between the two countries and hoping for eventual reunification mostly financed these. The International Tourism Free Zone of Geumgang mountain has been linked since 1999 by a maritime route from Donghae port, which is scheduled to become a Free Economic Zone. After success attracting South Korean visitors (from 12000 in 1998 to more than 1.2 million in 2005), the area has been inserted in a wider project opening more mountain area and expanding the zone to the northern Wonsan city. The Gaeseong Industrial Complex, located at $160 \mathrm{~km}$ south of Pyongyang in North Korea and 60 
km north of Seoul in South Korea, has been developed near the Demilitarised Zone (DMZ). It covers $24.5 \mathrm{~km}^{2}$ among the forecasted $65 \mathrm{~km}^{2}$, which shall include a new town of $6.47 \mathrm{~km}^{2}$ between 2007 and 2012. A qualified and cheap workforce (US\$57.5 a month against US\$449 in South Korea in 2003) is the main attraction for companies, which are mainly Korean. However, the United States' embargo on DPRK, through the Wassenaar Agreement (1996), restrains exports in general and controls the importation of technological products. As a consequence, most products made in Gaeseong are sent to South Korea before completion and are registered as South Korean products before being exported.

\subsection{Geographic and economic situation}

With a population of 23 million, North Korea has approximately half the population of South Korea on a slightly larger but more mountainous surface. The population concentrates mostly along the east and west coasts (see Figure 1), especially Pyongyang city and South Pyeongan province, which have been the most dynamic in the recent years, questioning the ideology of balanced regional development in a socialist country (Jo and Adler, 2002b).

\section{[INSERT FIGURE 1 ABOUT HERE: Population evolution]}

Industrial activities were sustained until North Korea could no longer rely on its neighbours for energy supplies, especially after the collapse of the socialist block (19891991). Thus, the end of former informal agreements had immediate consequences on the overall economy, as North Korea did not have enough capital to buy energy instead of exchanging it against other products. Mining, farming and transporting declined rapidly, leading the country to starvation, general crisis and stagnation. The other factor causing difficulty for North Korea was its substantial investments in defence and the heavy industry, 
which were not competitive in the age of globalisation marked by light industry and tertiary activities (Jo and Adler, 2002b).

The evolution of the North Korean economic structure reveals two distinct stages: the rise of mining and manufacturing sectors, which were up to $60 \%$ of the GDP at the expense of agriculture and services, and then the rapid decline of industrial activities from $60 \%$ to $26 \%$ around 2001 in favour of services (43.6\%) and agriculture (30.4\%) (Ahn, 2003). The growth of the service sector can be attributed to the increased role of the army in the economy, and to its construction projects related to hydro power plants, housing and highways.

Outside free trade zones and specialized zones, two other locations are of prime concern for economic development: the Nampo-Pyongyang corridor for manufacturing activities, and the northeastern coastal area for mining and raw material exports. The Daean Friendship Glass Factory opened in 2006 as a Chinese investment in the Nampo area of US\$24 million. The Nampo-Pyongyang corridor has received increased recognition from foreign players (Korea Times, 2000), because of its connection to DPRK's unique international airport and its 10-lanes highway.

Recently, major projects have been launched to restart the extraction of raw materials in DPRK. In Danchon, the world's third largest magnesite mine, a French company has obtained permission to mine for 50 years in exchange of providing hydro power plants to North Korea. The Korea Resources Corporation (KORES) and a North Korean company have also launched a joint-venture in Jeongchon, to exploit 1,830 tons of graphite a year, covering $20 \%$ of South Korea's needs. Rajin port is being leased to China for 50 years, together with the improvement of the highway link to the Chinese city of Hunchen and the creation of a logistics free zone in Namyang, Onsong County, at the border along the Tumen River. It aims at developing trade with the Chinese Jilin province and at fostering relationships between Japanese, South Korean companies seeking to establish manufacturing export plants in the 
area, and Chinese companies located in the neighbouring cities (Hankyoreh, 2006).

According to UNCTAD estimates, North Korea's Foreign Direct Investment (FDI) stock increased from US\$572 in 1990 to US\$1,022 in 2003, representing 3\% and $10 \%$ of national GNP respectively. This points to an increasing trend, but the amounts remain small. On one side, it can be argued that the low level of inward FDIs in North Korea is caused by its unattractive environment and by the failure of its government 'to convince the international business community regarding its economic reform policy’ (Lee, 2005). On the other side, according to Chabaud-Latour (2006), who manages the sole European consulting company registered in North Korea since 2001 involved in logistics, confection, energy and automobile parts, the very well educated and skilled manpower offers a considerable advantage over other Asian countries, even China. North Korea's decision to use the Euro as its foreign currency is definitely a political gesture against the U.S., but it also signifies the potential investment of European companies in North Korea as no historical or geopolitical issue is involved (Bridges, 2003).

\subsection{Foreign trade}

The foreign trade of North Korea has evolved through two major trends between 1990 and 2005. The first important trend is the distinction between a period of declining and unstable trade (1990-1998) and a period of stable growth (1998-2005). The second important trend is that, whatever the general evolution of foreign trade, the share of inter-Korean trade is constantly growing (Table 1). Overall foreign trade is known to be chronically in deficit as imports surpass exports.

The growth of north-south trade must not hide the more important increase of trade with China. Trade between the two nations has almost doubled between 2001 and 2005, and according to the Korea Trade and Investment Promotion Agency (KOTRA), 120 Chinese 
companies have already invested in North Korea, representing around US\$150 millions and $48 \%$ of North Korean exports (Pons, 2005). The modest but rapidly growing trade with Russia and Thailand has almost tripled in the same period, reflecting North Korea's increasing dependence on imported food and energy. In contrast, trade with Japan has dramatically decreased due to worsening diplomatic relations.

Also, north-south trade growth is hiding different realities, including the importance of humanitarian shipments which constitute between $25 \%$ and $60 \%$ of the products exported from south to north since 1998 (Table 2). In general, non-commercial exports make up a significant portion of the exports from south to north, of which the different cooperation projects (e.g. Mount Geumgang) and the material aid are major components.

[INSERT TABLE 1 ABOUT HERE: Trade by main partners]

[INSERT TABLE 2 ABOUT HERE: Trade between North Korea and South Korea]

General commercial exports to the north concern machinery and transport equipment, textile and chemical products through a regular larger share (more than 60\%), and exports related to processing trade are dominated by textile, electric and electronic products ( $80 \%$ to 90\%). Imports from north to south are increasing regularly in quantity, notably after 2002. These are mainly textile, metal and agricultural products for general imports and textile products for imports related to processing trade.

\section{The North Korean transport system}

\subsection{Logistics and inland transportation}

Transport infrastructures in North Korea are unsurprisingly less developed than its neighbours in terms of road network, airports and merchant fleet, but the railway network is 
highly electrified (Table 3). This reflects the effects of the Japanese occupation (1910-1945), and the strategy of developing a 'fully integrated and containerised transport system' (Ahn, 2003) centred on inland transportation, with a priority given to railways as in the Russian model $(90 \%)$. The modal split in North Korea is distributed among railways $(73.8 \%)$, roads (18.3\%), sea (7.9\%) in 1989 (Tsuji, 2000), what is confirmed by recent estimates with railways (70\%) roads (17\%), sea (10\%) and air (3\%) in 2005 (Roussin and Ducruet, 2006).

\section{[INSERT TABLE 3 ABOUT HERE: Transport infrastructures]}

Despite their importance, railways have been highly struck by the economic crisis that started to spread in every sector of DPRK in the 1970s. The lack of energy has forced using old Japanese steam trains fuelled with second-hand tires. Despite the abundance of coal in the country, it is now estimated that $70 \%$ of the entire power generation facilities are either abandoned or need urgent repairs, while $20 \%$ only of all factories are said to keep some activities (Ministry of Unification in South Korea, 2006).

Another consequence of isolation and energy shortages is the low road pavement rate of 7\% (Bang, 2004). This also reflects the governmental restriction and military control of circulation within the country, notably for Pyongyang where a special permit is required to enter. As a result, the time-distance by truck from Pyongyang to main cities is unrealistic and constantly increasing (Table 4), and truck drivers tend to avoid a voyage to the Northeast where several accidents have been reported (Cotton, 1996).

[INSERT TABLE 4 ABOUT HERE: Time and distance from Pyongyang to main cities]

The regional distribution of domestic transport activity shows a strong unbalance and 
relative disconnection between the western area, which occupies $40 \%$ of the total $(30 \%$ in South Pyongan, $10 \%$ in North Pyongan), and the eastern area, accounting for $41 \%$ of the total (24\% in North Hamgyeong, 17\% in South Hamgyeong) (Tsuji, 2005). Thus, South and North Korean companies involved in processing trade have to spend $40 \%$ of their manufacturing costs on logistics.

\subsection{Ports and maritime transportation}

Because the army controls North Korean ports, it is impossible to verify the published statistics on port infrastructures. Different estimations collected from various sources are not well matched (Table 5), notably for Cheongjin and Wonsan which show very contrasting profiles in terms of quay length and nautical depth.

\section{[INSERT TABLE 5 ABOUT HERE: Port infrastructures]}

Although maritime transport was destined 'to ensure coastal transport, expand railway connections and, in particular, improve foreign trade using ships' (Ahn, 2003) by the 19617 year Development Plan of North Korea, it has remained very limited as it is the case of former Soviet countries (Thorez, 1998b). Due to economic decline and isolation, port facilities have stagnated except for some investment in oil berths in the 1970s and storage facilities in the 1980s.

Nowadays, several sources indicate institutional and technical barriers affecting shipping, excessive logistics costs, and prolonged shipping time (Ahn, 2002). Still, the Incheon-Nampo round trip takes 24 hours for $100 \mathrm{~km}$, and it costs as much as the route to Europe: US\$1,000 to transport for one TEU (Ahn, 2001). Furthermore, ports collect exorbitant port-entry fees, making the cost three times higher than for connecting Tianjin in China. Especially, $45 \%$ of 
containers sent to North Korea return empty (Forster-Carter, 2001). Despite the failure of South Korean investments in new port facilities around Nampo (Yonhap News, 2005), following the strategy announced by Korea Container Terminal Authority (Lloyd's Register, 2005), a new container terminal has opened in 2006 (Lloyd's Register, 2006). This terminal is seen as a complement to the general cargo quay of Songgwan port built in 2001 closer to the West Sea Barrage (Jo and Ducruet, 2006). Although no specific facilities for handling containers are said to exist in North Korea (Kim, 2005), the Incheon-Nampo line carries most of inter-Korean containerised shipments (Korea Times, 2001; Ahn, 2002), notably with the South Korean company Kook Yang Shipping and the Trade of Fortune, sponsored by the South Korean Ministry of Unification through the Maritime Agreement signed in 2005 between the two countries.

\subsection{North Korean border trade in the Northeast Asian transport system}

The prospects for improving logistics at the borders reflect the strategies of North Korea's neighbours (Figure 3). China plans a six lane $67 \mathrm{~km}$ highway construction to connect Hunchen city, China and the Raseon Free-Trade Zone, as well as a dedicated terminal in Rajin. This would allow a shorter path for exporting Chinese manufactured goods to Japan and the Pacific. The strategy for the Raseon area is to attract Chinese trade by offering lower costs, enabling shipments to bypass the Yellow Sea and the Russian ports, which are frozen during winter and have lower capacity (Vladivostok, Vostochny, Nakhodka, Posyet and Zarubino). For Japan, the plan is for a direct maritime connection to the Trans-Siberia-Railroad (TSR) and the Trans-China-Railroad (TCR) transport system, given the recent rejection of the South Korean government to connect Busan, South Korea and Tsushima, Japan by a submarine tunnel. China also plans a second bridge to Sinuiju, a railway connection and the so-called green road which, in the future, could connect to the core region of Pyongyang and use the 
Amrok River (Yalu in Chinese) for barging to and from the border cities of Sinuiju, Dandong and the small island.

\section{[INSERT FIGURE 3 ABOUT HERE: Development projects in North Korea]}

South Korea seeks long-term interaction based on mutual benefits, but the scope of its projects in the North, apart from Gaeseong and Geumgang, are still limited because of politics. To strengthen regional cooperation, the South Korean government has proposed to make better use of the Han River, as a common resource for sand and barging, and of the Yaeseong River, to enable more direct exports from the Gaeseong Industrial Complex. Still, the demilitarised zone (DMZ) is a constraint and the inter-Korean railway has yet to be reconnected, but recent cancellation of the joint rail test-runs by North Korea reveals the unstable cooperation taking place between the two Koreas (Ministry of Unification in South Korea, 2006).

\section{Maritime transport and the economy}

\subsection{General trends and economic weight}

When comparing total trade and total shipping capacity (Figure 3), it is interesting to see that maritime activity has maintained in times of trade decline, notably from the mid-1990s to the early 2000s. This is better seen when estimating the share of sea trade in total trade (Figure 4). One ratio (a) is based on US\$250 per DWT, retained from the average ton-dollar values of Japanese and South Korean trade with North Korea, which occur dominantly by sea, and have been applied to total North Korean maritime traffic. Another ratio (b) distinguishes different types of traffics including container \& roll-on roll-off, general cargo, solid bulks, chemicals, and liquid bulks. It applies the reducing coefficient proposed by Charlier (1994) to 
obtain 'weighted tons' as a more realistic measure of the value of cargoes. Weighted tons are then transferred to dollars with the same value of US\$250. As a result, the two ratios give a very different importance to sea trade, with average shares of $26.7 \%$ for ratio (a) and $15.2 \%$ for ratio (b) along the period. In both cases, the importance of sea trade is higher than previous estimations - the intermediate share is likely to oscillate around $20 \%$ - but it varies over time. The different periods affecting the importance of sea trade can be distinguished as follows:

- the contraction of forelands stemming from the disconnection from the world system and the sudden ceasing of trade relationships with socialist countries (1985-1991);

- the effect of the construction and operation of the Rajin-Seonbong Free-Trade Zone experiment (1991-1993), for which maritime transport has been necessary to carry goods to the remote location;

- the continuous relationship with Japan and growing humanitarian aids (1994-2001) at a time of isolation, famine, and reinforced militarist government after the death of former president Kim Il-Sung;

- the effects of inter-Korean cooperation projects after the summit, and the increased trade with China (2002-2005), for which trade relationships are mostly continental and result in border trade through Sinuiju and the Demilitarised Zone (DMZ).

\subsection{Evolution of the port system}

The relative share of North Korean ports is a good indicator of the evolution of the whole economy (Figure 5). It clearly shows the shift of main port activities from the East to the West coast as a result of combined factors such as declining trade with Japan, growing isolation and economic decline of Eastern coastal cities, the increased primacy of the Pyongyang core region, and the emergence of the Pyongyang-Nampo corridor as the only area where 
industries keep a regular activity, benefiting from the highway network and the international airport. For the biggest eastern cities such as Cheongjin and Heungnam-Hamheung, one must not forget the importance of aids in the revival of their port activity, from 1999. The continued activity of Wonsan until 1998 can be attributed to the regular ferry link with Niigata, Japan. Since 2002, several issues have been regularly reported by Japanese authorities. These issues are drug trafficking, passenger safety and overloading, technical problems (e.g., lack of evacuation route signs, radio communication, and engine room fire extinguisher), oil spills, spying, and transfer of illegal money and nuclear weapons components. This has resulted in the banning of North Korean ships from Japanese ports (Lloyd's Register, 2002).

Compared to Taaffe et al.'s (1963) model that is defined by the concentration on one main port at the expense of smaller and peripheral ports in underdeveloped countries, we have in North Korea another phenomenon. The disconnection of landside relationship between port cities and the existence of two maritime facades enjoying privileged relationships with neighbouring trading partners is reducing the formation of a unique and dominant load centre which would concentrate the flows in order to serve the country's primate city. Notably, Nampo's share of total shipments by sea has exceeded 50\% only in 1997, 1998, 2003 and 2004, remaining around 30 or $40 \%$ for most of the last two decades. One explanation of the restart of port activities in smaller ports such as Haeju and Songjin may be the increased inland logistic barrier, as previously unused ports start to serve for transportation, either for commercial flows or aid imports. For Haeju, the current growth could also reflect recent barging activity with Incheon since 2004. But despite its proximity to Gaeseong Industrial Complex, there is no reported activity between the two areas because of poor road connection. The recent growth of Rajin, though it remains very modest, may also illustrate the impact of Chinese transit trade. 
Although this analysis shows partly the interplay of transport and development in North Korea through the evolution of vessel movements by port, a qualitative approach of the nature of the goods transported is needed.

[INSERT FIGURE 5 ABOUT HERE: Evolution of the port system]

\subsection{Maritime trade and port city specialization}

Given the irregularity of North Korean maritime activity based on tramping, the total vessel capacity by port has been distributed among three periods of seven years. Those periods correspond to important changes such as the collapse of the socialist block and the reforms, which have significantly affected the entire economy. As a base for analysing port activities, a synthesis of port and urban functions is provided (Table 6). It shows the traditional activities of the main port cities and the resources located in their close hinterland. As most cities tend to become isolated from each other because of logistic costs stemming from inland transport dereliction, it is believed that some factories maintain their activity in relation to their ports. Table 7 provides a synthesis of the vessel movements by type of ship and total capacity by North Korean port among the three periods.

The seafood processing and fish industry is probably one of the most stable in North Korea. This is because it does not necessitate large amounts of energy and is surrounded by a large consumer market consisting of Japan and South Korea. For most cities specialized in this activity (Haeju, Nampo, Rajin, Wonsan), the vessel traffic of fish products and refrigerated containers (reefer) is stable or increasing in recent years, except for Cheongjin and Heungnam where this was not specified as a core activity.

Two other sectors show a good number of coincidences. For chemical products, the distribution of vessel traffics echoes the specialization of four cities except Haeju, with a 
recent growth in Cheongjin and Heungnam-Hamheung, and a regular decline in Nampo and Wonsan. For machinery, the traffic of vehicles matches the specialization of Cheongjin, Heungnam-Hamheung, Nampo (Pyonghwa Automobiles), except from Wonsan. This traffic might also represent the imports of second-hand cars from Japan rather than the local industry. Finally, wood traffics coincides with the specialization of Heungnam-Hamheung, and Wonsan welcomes the majority of ro-ro and passenger traffics. Another interesting trend is that most cement traffics occur at the biggest cities (Cheongjin, Heungnam-Hamheung, and Nampo), reflecting the trend of construction, but not in Haeju where a cement factory is reported to exist, or Wonsan, which is supposed to handle cement flows. For oil and other liquids, the largest amounts in the first period well reflect the importance of Wonsan and Heungnam's petrochemical industries, but this traffic has been dramatically reduced and redistributed to Nampo and Cheongjin, the main markets (including Pyongyang).

\section{[INSERT TABLE 6 ABOUT HERE: Port-urban specialization of coastal cities]} [INSERT TABLE 7 ABOUT HERE: Distribution of traffics by type of ships, port \& period]

The two remaining categories can be distinguished according to their broad function, with bulks serving more heavy industries and construction, while general cargoes are better represented for the local consumer market and light industries. Although this distinction is obviously not perfect, it can help to assess the relative evolution of urban economies. As seen in Table 8, both traffics indicate the dramatic decline of the eastern cities. While Wonsan and Heungnam show a regular loss of traffics, Cheongjin and Rajin have increased their bulk traffics during the first period, probably because of their strategic situation between Japan and China. For Rajin, the growth is better explained by the import of primary products and construction materials for the preparation of the Rajin-Seonbong free-trade zone. Haeju and 
Songjin enjoy the highest growth rates, notably for general cargo, but the volumes remain small. At the end, Nampo is the only major port to maintain its activity along the period, with the lowest decline, thanks to its proximity to North Korea's largest industrial complex and primate city. General cargoes have dropped more rapidly than bulks, showing the specific tendency of the North Korean regime to support heavy rather than light industries. This global snapshot of the situation clearly indicates which coastal cities have been more struck by the economic collapse and isolation.

[INSERT TABLE 8 ABOUT HERE: Growth rates of bulk and general cargo traffics by port]]

\section{Conclusion}

This paper has proposed an analysis of cargo vessel movements at North Korean ports to evaluate the current situation of coastal urban economies and the effects of broader changes such as economic decline, isolation, economic reforms, and inland logistics dereliction on port activities. On one side, the activity of North Korean ports confirms the evolution of local industries, as their specialization is visible concerning minor traffics such as chemicals, vehicles, fish products, and oil products. On the other side, main traffics of bulk and general cargo are all reducing, reflecting the trend of economic decline throughout the country. However, coastal cities are responding differently to change. Smaller and peripheral ports such as Haeju and Songjin have seen their recent traffics growing rapidly, while Nampo, the port of Pyongyang, has the lowest decline and concentrates most of investments and traffics.

Given the difficulties of land transport, the application of a Chinese model of port development in North Korea could appear as one solution for upgrading coastal industries. However, this strategy is not yet adopted for a number of reasons. First, the inland location of main industrial areas (Pyongyang, Gaeseong) and the dereliction of eastern cities hamper the 
establishment of new industrial zones around port areas. Second, the current state of port infrastructures in North Korea and the distance to already existing foreign load centres such as Incheon, Busan, and Dalian, do not allow the replication of the Chinese model. In fact, the proximity of Hong Kong for spreading container technology and upgrading neighbouring Shenzhen ports has been crucial (Song, 2002). Since the Open Door Policy in 1978 followed by the creation of Special Economic Zones on coastal areas, Chinese industries have not been able to bypass Hong Kong for connecting directly global regular shipping lines through domestic ports until 1995 (Wang, 1998). Even today, Chinese hinterlands are not yet accessible to foreign freight forwarders, except for OOCL, the Hong Kong company, for ideological, historical and cultural reasons.

Despite the economic reforms, North Korean exports still face the Japanese and U.S. embargoes. Because the Peace Treaty is not yet signed by the U.S., accessing the Gaeseong Industrial Park either through the Demilitarised Zone (DMZ) or from Pyongyang faces several constraints, such as military control and unstable diplomatic relationships between the two Koreas. Thus, the improvement of logistics in North Korea, despite the new economic environment provided by the reforms, is hampered by a contradiction between closure and openness. This contradiction delays the possible effects of economic reforms on the transport system itself, such as infrastructure modernisation and free circulation. Still in North Korea, transport issues seem to be a restrictive factor for development, and it will take time until the country gains better recognition from the global community for its efforts towards openness, its comparative advantages for labour and industries, and its strategic location within Northeast Asia.

\section{References}

Ahn, M.Y., 2001, Slow boat to North Korea. Cargo News Asia, May $7^{\text {th }}$. 
Ahn, M.B., 2002, Restoration of the Seoul-Sinuiju line: review and outlook. East Asian Review, 14(1), pp. 107-119.

Ahn, C.Y., 2003, North Korea development report 2002/3 (Seoul: Korea Institute for Economic Policy).

Airriess, C.A., 1989, The spatial spread of container transport in a developing regional economy: North Sumatra, Indonesia. Transportation Research A: General, 23(6), pp. 453461.

Bang, H.K., 2004, Research notes: towards an integrated logistics system in Northeast Asia. East Asian Review, 16(2), pp. 111-121.

Bridges, B., 2003, Western Europe and North Korea: new openings and old problems. East Asia, 20(3), pp. 86-107.

Brodin, A., 2000, Ports in transition in countries in transition: the changing situation for ports in Russia and the Baltic States in times of geopolitical and economical transition (Gothenburg: University of Gothenburg).

Brodin, A., 2003, Baltic ports and Russian foreign trade: studies in the economic and political geography of transition (Gothenburg: University of Gothenburg).

Chabaud-Latour, P., 2006, Doing business in DPRK. Paper presented at the North Korea Forum of the Korea Research Institute for Human Settlements, Anyang, Korea, April $21^{\text {st }}$.

Charlier, J., 1994, On the concept of weighted tonnage in port economics: the example of the northern range. Cahiers Scientifiques du Transport, 29, pp. 75-84.

Cotton, J., 1996, China and Tumen river cooperation: Jilin's coastal development strategy. Asian Survey, 36, pp. 1086-1101.

Forster-Carter, A., 2001, The shipping forecast: choppy waters. Asia Times, February $15^{\text {th }}$. Hankyoreh, 2006, China, N.K. agree to trade zone along border. Hankyoreh, http://english.hani.co.kr/arti/english_edition/e_international/150123.html 
Hoyle, B.S., 1974, Spatial analysis and the less-developed countries. In: Spatial Aspects of Development, edited by B.S. Hoyle (London, New York: John Wiley and Sons), pp. 1-27.

Hoyle, B.S., 1981, Cityport industrialization and regional development in less-developed countries: the tropical Africa experience. In: Cityport Industrialization and Regional Development, edited by B.S. Hoyle and D.A. Pinder (London: Pergamon Press), 281-303.

Hoyle, B.S., and Hilling D., 1984, Seaports and development strategies. In: Seaport Systems and Spatial Change, edited by B.S. Hoyle and D. Hilling (Chichester: John Wiley \& Sons Ltd.), pp. 461-469.

IRU, 1996, World transport data (Geneva: International Road Transport Union).

Jauernig, C., and Roe, M., 2000, International freight transport in Lithuania. Transport Reviews, 20(4), pp. 447-468.

Jauernig, C., and Roe, M., 2001, International logistics in Lithuania at a time of transition. Transport Reviews, 21(1), pp. 117-135.

Jo, J.C., and Adler, S., 2002a, Planning in the socialist developing country: the case of North Korea. Habitat International, 26, pp. 251-267.

Jo, J.C., and Adler, S., 2002b, North Korean planning: urban changes and regional balance. Cities, 19(3), pp. 205-215.

Jo, J.C., and Ducruet, C., 2006, Maritime trade and port evolution in a socialist developing country: Nampo, gateway of North Korea. The Korea Spatial Planning Review, 51, pp. 3-24. Jung Eliot, S.H., Kim, Y.S., and Kobayashi, T., 2003, North Korea's special economic zones: obstacles and opportunities. In: Confrontation and Innovation on the Korean Peninsula, edited by Lister James M. (Washington: The Korea Economic Institute), pp. 43-59.

Kim, H.S., Lee, S.W., and Yoo, J.M., 1998, The directions of the port development policy in the unified Korea (Seoul: Korea Maritime Institute).

Kim, W.B., 2005, International cooperation for infrastructure development in North Korea. 
Building an Integrated Infrastructure in the Korean Peninsula, International Workshop, Korea Research Institute for Human Settlements, September $29^{\text {th }}$, Anyang, South Korea.

Korea Strategic Data, 2006, Information center for your business in North Korea. http://www.koreainform.com

Korea Times, 2000, Pyongyang-Nampo belt most promising for inter-Korean projects. July $15^{\text {th }}$.

Korea Times, 2001, Inter-Korean processing trade set to resume. February $20^{\text {th }}$.

Ledger, G., and Roe, M., 1996, East European change and shipping policy (Aldershot: Avebury).

Lee, C.J., 2005, Trade and investment in North Korea (Seoul: Korea Institute for International Economic Policy).

Lloyd's List, 2004, Ports of the world 2005 (London: Informa Publications Ltd.).

Lloyd's Register ${ }^{1}, 2002$, Japan to target North Korean ships. December $10^{\text {th }}$.

Lloyd's Register, 2005, South Korean investors eye North's Nampo. September $22^{\text {nd }}$.

Lloyd's Register, 2006, North Korea completes container berth. May $12^{\text {th }}$.

Ministry of Unification ${ }^{2}$, 2004, North Korea's recent trend toward economic opening and administrative unit reorganization. January.

Ministry of Unification, 2005, Recent changes in North Korea. March $14^{\text {th }}$.

Ministry of Unification, 2005, Changes in North Korea for the past five years. December $23^{\text {rd }}$. Ministry of Unification, 2006, Statistics on North Korea in general. February $14^{\text {th }}$.

Ministry of Unification, 2006, The status on North Korea's foreign trade and economic cooperation in 2005 . February $16^{\text {th }}$.

Ministry of Unification, 2006, The estimate of North Korea's foreign trade in 2005. May $15^{\text {th }}$.

Ministry of Unification, 2006, Comment on the postponement of test-run of inter-Korean

\footnotetext{
${ }^{1} \mathrm{http}: / /$ www.portguide.com

2 http://www.unikorea.go.kr/index.jsp
} 
trains. May.

Pons, P., 2005, La Chine met sous sa coupe l'économie nord-coréenne. Le Monde, October $31^{\text {th }}$.

Robinson, R., 1981, Industrialization, new ports and spatial development strategies in lessdeveloped countries: the case of Thailand. In: Cityport Industrialization and Regional Development, edited by B.S. Hoyle and D.A. Pinder (London: Pergamon Press), pp. 305-322.

Roussin, S., and Ducruet, C., 2006, Logistic perspectives in DPRK. Proceedings of the Annual Fall Meeting of the Korean Society of Coastal and Ocean Engineers, Seoul, Korea.

Song, D.W., 2002, Regional container port competition and co-operation : the case of Hong Kong and South China. Journal of Transport Geography, 10(2), pp. 99-110.

Taylor, Z., 1984, Seaport development and the role of the state: the case of Poland. In: Seaport Systems and Spatial Change, edited by B.S. Hoyle and D. Hilling (Chichester: John Wiley \& Sons Ltd.), pp. 217-238.

Tsuji, H., 2000, Transportation corridor development in the Tumen River Region (Niigata: Economic Research Institute for Northeast Asia).

Tsuji, H., 2005, The transport infrastructure of the DPRK (Niigata: Economic Research Institute for Northeast Asia).

Thorez, P., 1998a, Le transport maritime dans les pays issus de l'ex-URSS. Le Courrier des Pays de l'Est, 426, pp. 18-52.

Thorez, P., 1998b, La difficile mutation des transports maritimes dans la CEI. Bulletin de l'Association des Géographes Français, 1, pp. 343-362.

Wang, J.J., 1998, A container load center with a developing hinterland: a case study of Hong Kong. Journal of Transport Geography, 6(3), pp. 187-201.

Yonhap News, 2005, South Korea to develop North Korean port of Nampo. January $4^{\text {th }}$. 
Table 1: Main trading partners of North Korea, 2001-2005 (Unit: millions US\$)

\begin{tabular}{lrrrrrrrrrr}
\hline & \multicolumn{2}{c}{2001} & \multicolumn{2}{c}{2002} & \multicolumn{2}{c}{2003} & \multicolumn{2}{c}{2004} & \multicolumn{2}{c}{2005} \\
& Trade & Share & Trade & Share & Trade & Share & Trade & Share & Trade & Share \\
\hline China & 737 & 27.6 & 738 & 25.4 & 1022 & 32.8 & 1385 & 39.0 & 1580 & 39.0 \\
South Korea & 403 & 15.1 & 641 & 22.1 & 724 & 23.2 & 697 & 19.6 & 1044 & 25.8 \\
Thailand & 130 & 4.9 & 216 & 7.5 & 254 & 8.2 & 329 & 9.3 & 329 & 8.1 \\
Japan & 474 & 17.8 & 369 & 12.7 & 265 & 8.5 & 252 & 7.1 & 194 & 4.7 \\
Russia & 68 & 2.6 & 80 & 2.8 & 118 & 3.8 & 213 & 6.0 & 232 & 5.7 \\
India & 157 & 5.9 & 191 & 6.6 & 158 & 5.1 & 135 & 3.8 & N/A & N/A \\
Singapore & N/A & N/A & N/A & N/A & N/A & N/A & 56 & 1.5 & 80 & 1.9 \\
EU countries & N/A & N/A & N/A & N/A & N/A & N/A & 261 & 7.3 & 292 & 7.2 \\
Others & 702 & 26.3 & 633 & 22.9 & 572 & 18.4 & 226 & 6.3 & 294 & 7.2 \\
Total & 2673 & 100.0 & 2902 & 100.0 & 3115 & 100.0 & 3554 & 100.0 & 4045 & 100.0 \\
\hline Sources: Korea
\end{tabular}

Sources: Korea Trade and Investment Promotion Agency 
Table 2: Trade between North and South Korea, 1998-2006 (unit: 000s US\$)

\begin{tabular}{|c|c|c|c|c|c|c|c|c|c|c|c|c|c|c|c|c|c|c|}
\hline & 1998 & $\%$ & 1999 & $\%$ & 2000 & $\%$ & 2001 & $\%$ & 2002 & $\%$ & 2003 & $\%$ & 2004 & $\%$ & 2005 & $\%$ & 2006 & $\%$ \\
\hline OTAL TRADE & 1693000 & 100.00 & 1790000 & 100.00 & 2395000 & 100.00 & 2619000 & 100.00 & 2839000 & 100.00 & 3018000 & 100.00 & 3547000 & 100.00 & 4044000 & 100.00 & & \\
\hline ITER-KOREAN TRADE & 251158 & 14.83 & 310024 & 17.32 & 425686 & 17.77 & 349172 & 13.33 & 579476 & 20.41 & 627488 & 20.79 & 687874 & 19.39 & 1044431 & 25.82 & 129590 & \\
\hline IMPORTS FROM NORTH & 123357 & 49.12 & 113697 & 36.67 & 152912 & 35.92 & 155988 & 44.67 & 249051 & 42.98 & 245464 & 39.12 & 257946 & 37.50 & 340916 & 32.64 & 55159 & 42.56 \\
\hline Agriculture, forestry and fishing & 29319 & 23.77 & 43903 & 38.61 & 72108 & 47.16 & 74602 & 47.83 & 92634 & 37.19 & 103696 & 42.25 & 98992 & 38.38 & 112242 & 32.92 & 16975 & 30.78 \\
\hline hemical pro & 260 & 1.83 & 1992 & 1.75 & 1162 & 0.76 & 0 & 0.00 & 0 & 0.00 & 0 & 0.00 & 0 & 0.00 & 0 & 0.00 & 0 & \\
\hline products & 3596 & 2.92 & 2726 & 1.88 & 402 & 5.40 & 0 & 4.50 & 0 & 3.03 & 0 & 0.00 & 0 & 0.00 & 22500 & 3.61 & 4272 & \\
\hline Iron, st & 22624 & 18.34 & 14982 & 13.18 & 11697 & 7.65 & 8786 & 5.63 & 14875 & 5.97 & 20941 & 8.53 & 39702 & 15.39 & 47784 & 14.02 & 6206 & 11.2 \\
\hline - & 651 & 0.53 & 815 & 0.72 & 1467 & 0.96 & 1704 & 1.09 & 0 & 0.00 & 0 & 0.00 & 0 & 0.00 & 0 & 0.00 & 0 & \\
\hline Miner & 482 & 0.39 & 2141 & 2.40 & 8264 & 0.26 & 7011 & 0.00 & 7541 & 0.00 & 0 & 0.00 & 0 & 0.00 & 12306 & 6.60 & 2846 & \\
\hline Textile & 54129 & 43.88 & 43183 & 37.98 & 53957 & 35.29 & 52886 & 33.90 & 75575 & 30.35 & 87656 & 35.71 & 99233 & 38.47 & 122034 & 35.80 & 19643 & 35.61 \\
\hline Other & 6035 & 4.89 & 2108 & 1.85 & 3759 & 2.46 & 0 & 0.00 & 0 & 0.00 & 0 & 0.00 & 0 & 0.00 & 0 & 0.00 & 0 & 0.0 \\
\hline Con & & & & & & & & 6.28 & & 99.72 & & 98.32 & & 99.95 & & 99.92 & 55159 & 100. \\
\hline Proces & & & & & & & 48286 & 46.70 & 91697 & 36.92 & 99672 & 41.30 & 115152 & 40.84 & 194029 & 56.91 & 21769 & 39.4 \\
\hline Commercial transactions & & & & & & & 42198 & 40.81 & 156663 & 63.08 & 145877 & 60.44 & 142666 & 59.11 & 29637 & 8.69 & 6549 & 11.8 \\
\hline Gener & & & & & & & 0 & 0.00 & 0 & 0.00 & 0 & 0.00 & 0 & 0.00 & 132855 & 38.97 & 26841 & 48.6 \\
\hline & & & & & & & 12239 & 7.85 & 978 & 0.39 & 4115 & 1.68 & 128 & 0.05 & 279 & 0.08 & $\mathbf{0}$ & \\
\hline Mount Geumgang & & & & & & & 2168 & 99.96 & 160 & 16.36 & 0 & 0.00 & 0 & 0.00 & 0 & 0.00 & 0 & \\
\hline Cooperation projects & & & & & & & 5 & 0.04 & 816 & 83.44 & 0 & 0.00 & 0 & 0.00 & 0 & 0.00 & 0 & \\
\hline LWR project & & & & & & & 0 & 0 & 1 & 0.10 & 0 & 0.00 & 0 & 0.00 & 0 & 0.00 & 0 & \\
\hline
\end{tabular}

\section{EXPORTS TO NORTH}

Agriculture, forestry and fishing

Chemical product

Electric and electronic products

Household products

Iron, steel and other metal

Machinery and transport equipme

Non-metallic mineral products

Plastic, rubber and leather products

Primary products

Textile

Others

Humanitarian assistance

NGOs

Korea National Red Cross (\%)

NGOs (\%)

Governmen

Bilateral

World Food Programme (WFP)

World Health Organization (WHO)

WMO

UNICEF

FAO

Other

Non Commercial Exports

Cooperation project

LWR project

KEDO heavy oil

Material aid

Mount Geumgang

Other joint ventures

Other

Commercial Exports

Business-based transactions

Processing on commissio $\begin{array}{llllllllllllllllll}127801 & 50.88 & 196327 & 63.33 & 272774 & 64.08 & 193184 & 55.33 & 330425 & 57.02 & 382024 & 60.88 & 429928 & 62.50 & 703515 & 67.36 & 74431 & 57.43\end{array}$ $\begin{array}{lllllllllllllllllll}2962 & 2.32 & 0 & 0.00 & 0 & 0.00 & 0 & 0.00 & 97944 & 29.64 & 114220 & 29.90 & 56774 & 13.21 & 110313 & 15.68 & 5200 & 6.99\end{array}$ $\begin{array}{lllllllllllllllllll}4251 & 3.33 & 42586 & 21.69 & 95526 & 35.02 & 59336 & 30.71 & 75222 & 22.77 & 76577 & 20.05 & 128461 & 29.88 & 224891 & 31.97 & 11963 & 16.07\end{array}$ $\begin{array}{llllllllllllllllll}4235 & 3.31 & 5359 & 2.49 & 28101 & 10.30 & 10035 & 5.20 & 20480 & 6.20 & 19523 & 5.11 & 29392 & 6.84 & 27134 & 3.86 & 8631 & 11.60\end{array}$

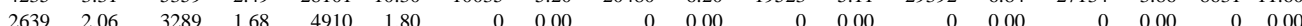
$\begin{array}{llllllllllllllllll}8780 & 6.87 & 15732 & 8.01 & 13998 & 5.13 & 10376 & 5.37 & 25008 & 7.57 & 22810 & 5.97 & 14290 & 3.32 & 21468 & 3.05 & 5443 & 7.31\end{array}$

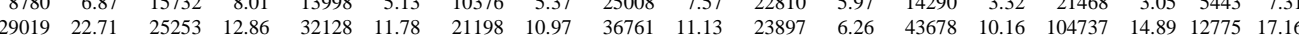
$\begin{array}{llllllllllllllllll}21346 & 16.70 & 43820 & 22.32 & 20202 & 7.41 & 7036 & 3.64 & 0 & 0.00 & 0 & 0.00 & 0 & 0.00 & 24312 & 3.46 & 4644 & 6.24\end{array}$

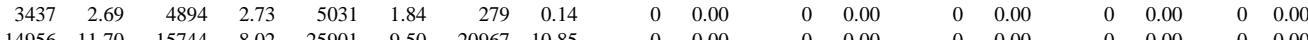

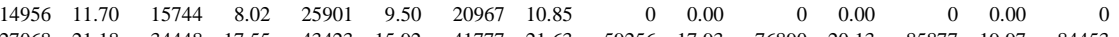
$\begin{array}{rrrrrrrrrrrrrrrrrr}27068 & 21.18 & 34448 & 17.55 & 43423 & 15.92 & 41777 & 21.63 & 59256 & 17.93 & 76890 & 20.13 & 85877 & 19.97 & 84453 & 12.00 & 11346 & 15.24\end{array}$

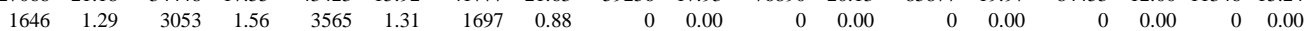

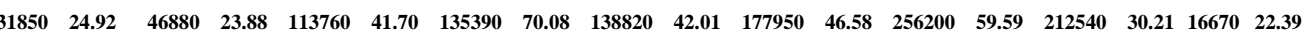

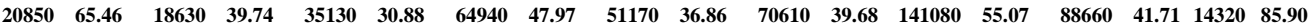
$\begin{array}{lllllllllllllll}20850 & 100.00 & 13065 & 70.13 & 9416 & 26.80 & 22000 & 33.88 & 6923 & 13.53 & 5860 & 8.30 & 37000 & 26.23\end{array}$ $\begin{array}{lllllllllllllll}0 & 0.00 & 5565 & 29.87 & 25174 & 73.20 & 42940 & 66.12 & 44247 & 86.47 & 64750 & 91.70 & 104080 & 73.77\end{array}$

$\begin{array}{llllllllllllllllll}11000 & 34.54 & 28250 & 60.26 & 78630 & 69.12 & 70450 & 52.03 & 87650 & 63.14 & 107340 & 60.32 & 115120 & 44.93 & 123880 & 58.29 & 2350 & 14.10\end{array}$ $\begin{array}{lrrrrrrrrrrrrr}0 & 0.00 & 28250 & 100.00 & 78630 & 100.00 & 65770 & 93.36 & 69670 & 79.49 & 89250 & 83.15 & 300 & 0.26\end{array}$

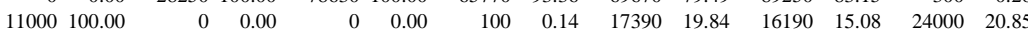

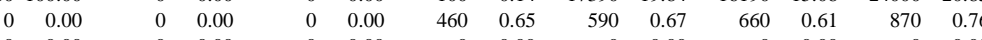
$\begin{array}{llllllllllllll}0 & 0.00 & 0 & 0.00 & 0 & 0.00 & 0 & 0.00 & 0 & 0.00 & 0 & 0.00 & 0 & 0.00\end{array}$ $\begin{array}{llllllllllllll}0 & 0.00 & 0 & 0.00 & 0 & 0.00 & 0 & 0.00 & 0 & 0.00 & 500 & 0.47 & 1000 & 0.87\end{array}$ $\begin{array}{llllllllllllll}0 & 0.00 & 0 & 0.00 & 0 & 0.00 & 0 & 0.00 & 0 & 0.00 & 0 & 0.00 & 0 & 0.00\end{array}$

$\begin{array}{llllllllllllll}0 & 0.00 & 0 & 0.00 & 0 & 0.00 & 4120 & 5.85 & 0 & 0.00 & 740 & 0.69 & 88950 & 77.27\end{array}$

$\begin{array}{lllllllllllllll}54703 & 42.80 & 48675 & 24.79 & 170396 & 62.47 & 51446 & 26.63 & 267600 & 80.99 & 252017 & 65.97 & 339809 & 79.04\end{array}$ $\begin{array}{rrrrrrrrrrrrrr}900 & 1.65 & 0 & 0.00 & 0 & 0.00 & 5889 & 11.45 & 10363 & 3.87 & 1218 & 0.48 & 47922 & 14.10\end{array}$ $\begin{array}{lllllllllllllll}1800 & 3.29 & 6761 & 13.89 & 35609 & 20.90 & 16701 & 32.46 & 55260 & 20.65 & 20307 & 8.06 & 448 & 0.13\end{array}$ $\begin{array}{llllllllllllll}12830 & 23.45 & 20059 & 41.21 & 0 & 0.00 & 2878 & 5.59 & 2041 & 0.76 & 0 & 0.00 & 0 & 0.00\end{array}$ $\begin{array}{lllllllllllllll}15052 & 27.52 & 2906 & 5.97 & 104478 & 61.31 & 20128 & 39.12 & 188995 & 70.63 & 217317 & 86.23 & 250076 & 73.59\end{array}$ $\begin{array}{lllllllllllllll}24121 & 44.09 & 18810 & 38.64 & 14606 & 8.57 & 4438 & 8.63 & 10941 & 4.09 & 13175 & 5.23 & 41363 & 12.17\end{array}$ $\begin{array}{llllll}139 & 0.29-6943 & 4.07 & 1412 & 2.74 & \end{array}$

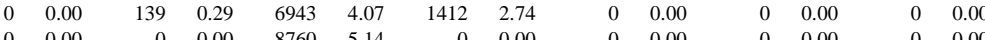

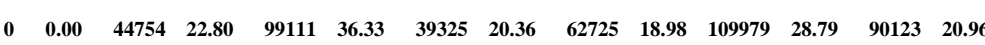
$\begin{array}{llllllllllllll}0 & 0.00 & 12414 & 27.74 & 36499 & 36.83 & 10025 & 25.49 & 4193 & 6.68 & 45932 & 41.76 & 25641 & 28.45\end{array}$

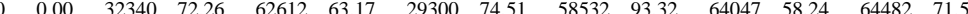

PROCESSING TRADE

$\begin{array}{llllllllllll}103465 & 29.63 & 150222 & 25.92 & 163519 & 26.06 & 175506 & 25.51 & 207837 & 19.9 & 40525 & 31.27\end{array}$

Imports from North

Agriculture, forestry and fishing

Textile

Electric and electronic products

Chemical products

Machinery and transport equipment

Household products

Others

Exports to North

Primary products

Textile

Electric and electronic products

Machinery and transport equipment

Plastic, rubber and leather products

Iron and other metals

Household products

Agriculture, forestry and fishing

Source: Ministry of Unification in South Korea

(a) The year 2006 comprises only February and March

(b) 1999 and 2001 lack of data for the type of exports.

\begin{tabular}{|c|c|c|c|c|c|c|c|}
\hline 62166 & 100.00 & 91690 & 100.00 & 99472 & 100.00 & 107674 & 100.00 \\
\hline 2107 & 3.39 & 1669 & 1.82 & 0 & 0.00 & 0 & 0.00 \\
\hline 47219 & 75.96 & 75244 & 82.06 & 87252 & 87.72 & 92679 & 86.07 \\
\hline 7124 & 11.46 & 7233 & 7.89 & 6373 & 6.41 & 7979 & 7.41 \\
\hline 546 & 0.88 & 0 & 0.00 & 0 & 0.00 & 0 & 0.00 \\
\hline 0 & 0.00 & 1790 & 1.95 & 0 & 0.00 & 0 & 0.00 \\
\hline 0 & 0.00 & 739 & 0.81 & 0 & 0.00 & 0 & 0.00 \\
\hline 3863 & 6.21 & 909 & 0.99 & 0 & 0.00 & 0 & 0.00 \\
\hline 41299 & 100.00 & 58532 & 100.00 & 64047 & 100.00 & 67832 & 100.00 \\
\hline 1161 & 2.81 & 0 & 0.00 & 0 & 0.00 & 0 & 0.00 \\
\hline 26903 & 65.14 & 41889 & 71.57 & 50836 & 79.37 & 55020 & 81.11 \\
\hline 7006 & 16.96 & 7120 & 12.17 & 6875 & 10.73 & 6925 & 10.21 \\
\hline 2711 & 6.57 & 80 & 0.14 & 0 & 0.00 & 0 & 0.00 \\
\hline 675 & 1.64 & 1134 & 1.94 & 0 & 0.00 & 0 & 0.00 \\
\hline 232 & 0.56 & 0 & 0.00 & 0 & 0.00 & 0 & 0.00 \\
\hline 0 & 0.00 & 1495 & 2.55 & 1927 & 3.01 & 222 & 0.33 \\
\hline 0 & 0.00 & 972 & 1.66 & 0 & 0.00 & 0 & 0.00 \\
\hline 70 & 0.17 & 0 & 0.00 & 0 & 0.00 & 0 & 0.00 \\
\hline
\end{tabular}


Table 3: Basic territorial characteristics of North Korea and neighbouring countries, 1995-2005

\begin{tabular}{|c|c|c|c|c|c|c|c|c|c|c|c|c|c|c|}
\hline $\begin{array}{l}\vec{E} \\
\text { 言 } \\
\text { D. }\end{array}$ & 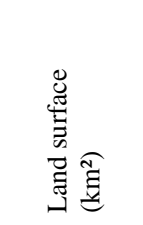 & 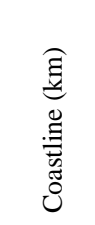 & 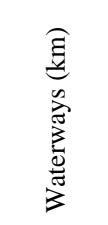 & $\stackrel{\vec{d}}{\grave{\nu}}$ & 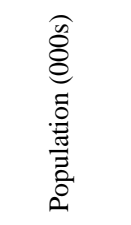 & 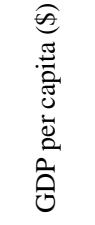 & 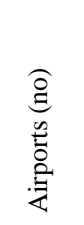 & 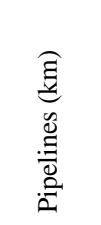 & 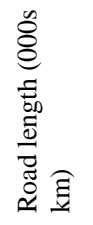 & 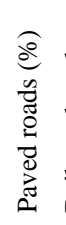 & 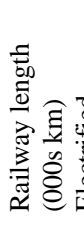 & 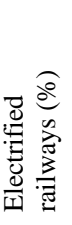 & 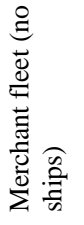 & 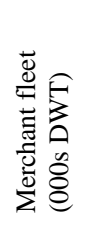 \\
\hline \multirow{2}{*}{ DPRK } & \multirow{2}{*}{120,410} & \multirow{2}{*}{2,495} & \multirow{2}{*}{2,250} & 1995 & 23,486 & 920 & 49 & 37 & 30 & 6.2 & 4 & 69.1 & 87 & $\overline{1,149}$ \\
\hline & & & & 2005 & 22,912 & 1,800 & 78 & 154 & 31 & 6.4 & 5 & 67.1 & 238 & 1,389 \\
\hline \multirow{2}{*}{ ROK } & \multirow{2}{*}{98,190} & \multirow{2}{*}{2,413} & \multirow{2}{*}{1,608} & 1995 & 45,553 & 11,270 & 114 & 455 & 63 & 72.4 & 3 & 7.7 & 412 & 9,985 \\
\hline & & & & 2005 & 48,422 & 20,300 & 179 & 2,260 & 97 & 76.5 & 6 & 38.6 & 601 & 11,081 \\
\hline \multirow{2}{*}{ RUSSIA } & \multirow{2}{*}{$16,995,800$} & \multirow{2}{*}{37,653} & \multirow{2}{*}{72,000} & 1995 & 149,909 & 4,820 & 2,517 & 203,000 & 934 & 22.3 & 87 & 24.6 & 800 & 10,128 \\
\hline & & & & 2005 & 143,420 & 10,700 & 640 & 239,439 & 537 & 32.5 & 154 & 46.2 & 1,194 & 5,505 \\
\hline \multirow{2}{*}{ JAPAN } & \multirow{2}{*}{377,835} & \multirow{2}{*}{29,751} & \multirow{2}{*}{1,770} & 1995 & 125,506 & 20,200 & 175 & 2,006 & 1,111 & 67.8 & 23 & 40.4 & 851 & 27,292 \\
\hline & & & & 2005 & 127,417 & 30,400 & 174 & 2,949 & 1,177 & 77.7 & 27 & 70.0 & 702 & 12,680 \\
\hline \multirow{2}{*}{ CHINA } & \multirow{2}{*}{$9,326,410$} & \multirow{2}{*}{14,500} & \multirow{2}{*}{121,557} & 1995 & $1,203,097$ & 2,500 & 204 & 17,000 & 1,029 & 16.5 & 65 & 10.9 & 1,628 & 24,027 \\
\hline & & & & 2005 & $1,306,313$ & 6,200 & 472 & 33,648 & 1,809 & 79.9 & 71 & 25.1 & 1,649 & 27,749 \\
\hline
\end{tabular}

Source: CIA, The World Factbook, 1995 \& 2005

Table 4: Time and distance from Pyongyang to main cities

\begin{tabular}{lccc}
\hline \multicolumn{1}{c}{ Pyongyang to: } & Distance $(\mathrm{km})$ & \multicolumn{2}{c}{ Travel time by truck (hours) } \\
\hline Nampo & 60 & 2000 & 2005 \\
Sariwon & 70 & N/A & 1 \\
Haeju & 120 & N/A & 2 \\
Gaeseong & 160 & N/A & 3 \\
Sinuiju & 230 & 5 & 8 \\
Wonsan & 230 & 2.5 & 7 \\
Hamheung & 430 & 5.5 & 7 \\
Kanggyae & 500 & 20 & Out of reach \\
Cheongjin & 960 & 15 & Out of reach \\
Hyesan & 1260 & 22 & Out of reach \\
Raseon & 1400 & 25 & Out of reach \\
\hline
\end{tabular}

Sources: World Food Programme, 2003; Korea Strategic Data, 2006

Table 5: Infrastructure characteristics of North Korean ports

\begin{tabular}{|c|c|c|c|c|c|c|}
\hline & $\begin{array}{c}\text { Stevedoring } \\
\text { capacity (tons) }\end{array}$ & $\begin{array}{c}\text { Maximum } \\
\text { Quay length (m) }\end{array}$ & $\begin{array}{c}\text { Minimum } \\
\text { Quay length (m) }\end{array}$ & $\begin{array}{l}\text { Maximum } \\
\text { Depth (m) }\end{array}$ & $\begin{array}{l}\text { Minimum } \\
\text { Depth }(\mathrm{m})\end{array}$ & $\begin{array}{l}\text { Berth capacity } \\
\text { (tons) }\end{array}$ \\
\hline Cheongjin & 800 & 5,270 & 2,138 & 10 & 8.5 & 20,000 \\
\hline Haeju & 240 & 1,350 & 1,305 & 12 & 7 & 10,000 \\
\hline Heungnam & 400 & 2,061 & 1,630 & 13 & 6.7 & 20,000 \\
\hline Nampo & 750 & 2,510 & 1,694 & 13.5 & 10 & 25,000 \\
\hline Rajin & 300 & 4,340 & 2,280 & 11 & 10 & 15,000 \\
\hline Seonbong & 200 & 2,515 & 456 & 23 & 7 & 5,000 \\
\hline Songrim & 100 & 700 & 400 & 11 & 10 & 15,000 \\
\hline Wonsan & 169 & 2,970 & 470 & 12.8 & 6.1 & 10,000 \\
\hline
\end{tabular}

Sources: Asia Trade Hub, 2005; Lloyd's Ports of the World 2005; Portguide 2006 
Table 6: Traditional functions of North Korean port cities

\begin{tabular}{|c|c|c|c|}
\hline Port city & Main port functions & Main urban functions & Hinterland (natural resources) \\
\hline Cheongjin & $\begin{array}{l}\text { Coals } \\
\text { Containers } \\
\text { General cargo } \\
\text { Grains } \\
\text { Steel }\end{array}$ & $\begin{array}{c}\text { Chemicals } \\
\text { Equipollent industry } \\
\text { Locomotive plant } \\
\text { Machinery } \\
\text { Rubber factory } \\
\text { Steel and fiber industry center } \\
\text { Shipyard }\end{array}$ & $\begin{array}{c}\text { Coal field } \\
\text { Cobalt } \\
\text { Nickel }\end{array}$ \\
\hline Haeju & $\begin{array}{c}\text { Cement } \\
\text { Ore } \\
\text { Zinc concentrates }\end{array}$ & $\begin{array}{c}\text { Agriculture (granary area) } \\
\text { Cement factory } \\
\text { Chemical products } \\
\text { Marine products } \\
\text { Shipbuilding \& repair } \\
\text { Steel } \\
\text { Chemical \& fertilizer industrial complex }\end{array}$ & Graphite \\
\hline $\begin{array}{l}\text { Heungnam } \\
\text { (Hamheung) }\end{array}$ & $\begin{array}{c}\text { Fertilizers } \\
\text { Magnesia clinker }\end{array}$ & $\begin{array}{c}\text { Machines } \\
\text { Textiles } \\
\text { Wood chip processing } \\
\text { Chemicals } \\
\text { Electronics }\end{array}$ & $\begin{array}{c}\text { Tungsten } \\
\text { Zinc }\end{array}$ \\
\hline Nampo & $\begin{array}{l}\text { Cements } \\
\text { Coals } \\
\text { Sundries }\end{array}$ & $\begin{array}{c}\text { Nampo Glass Corporation } \\
\text { Nampo Fishery Complex } \\
\text { Nampo Smelter Complex } \\
\text { Pyonghwa Automobiles } \\
\text { Shipbuilding \& repair industry center } \\
\text { Construction }\end{array}$ & $\begin{array}{l}\text { Coal } \\
\text { Iron ore } \\
\text { Zinc }\end{array}$ \\
\hline $\begin{array}{c}\text { Rajin } \\
\text { (Raseon) }\end{array}$ & $\begin{array}{c}\text { Coals } \\
\text { Crude oil } \\
\text { Fertilizers } \\
\text { Petrochemical products } \\
\text { Timber } \\
\text { Sundries }\end{array}$ & $\begin{array}{c}\text { Electric power plant } \\
\text { Oil-fired power plant and oil refinery } \\
\text { Real estate } \\
\text { Retailing } \\
\text { Seafood \& food processing } \\
\text { Tourism } \\
\text { Transport }\end{array}$ & $\begin{array}{l}\text { Uranium mine } \\
\text { Coal field }\end{array}$ \\
\hline $\begin{array}{c}\text { Songjin } \\
\text { (Kimchaek) }\end{array}$ & - & Steel mill & $\begin{array}{l}\text { Coal } \\
\text { Copper } \\
\text { Graphite } \\
\text { Iron ore } \\
\text { Lead } \\
\text { Magnesite }\end{array}$ \\
\hline $\begin{array}{c}\text { Songrim } \\
\text { (Pyongyang) }\end{array}$ & $\begin{array}{l}\text { Coals } \\
\text { Iron ore } \\
\text { Oil }\end{array}$ & Hwanghae Steel Mill & $\begin{array}{l}\text { Gold } \\
\text { Silver }\end{array}$ \\
\hline Wonsan & $\begin{array}{c}\text { Cement } \\
\text { Marine products }\end{array}$ & $\begin{array}{c}\text { Aquatic product processing plant } \\
\text { Cement factory } \\
\text { Chemistry enterprise } \\
\text { Fish \& rice processing } \\
\text { Leather goods } \\
\text { Machines } \\
\text { Manufacture of locomotives } \\
\text { Shipyard } \\
\text { Textiles }\end{array}$ & - \\
\hline
\end{tabular}

Source: compiled from various sources 
Table 7: Specialisation of North Korean ports (Unit: 000s \& \%DWT)

\begin{tabular}{|c|c|c|c|c|c|c|c|c|c|c|c|c|c|c|c|c|c|c|c|c|c|c|c|c|c|c|c|c|}
\hline \multirow[t]{2}{*}{$\begin{array}{l}\hat{0} \\
\overrightarrow{0} \\
\stackrel{0}{0}\end{array}$} & \multirow[t]{2}{*}{$\begin{array}{l}\overrightarrow{0} \\
\frac{0}{0} \\
2\end{array}$} & \multicolumn{2}{|c|}{ 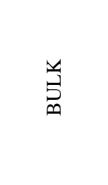 } & \multicolumn{2}{|l|}{$\sum_{\text {至 }}^{\sum_{U}^{-1}}$} & \multicolumn{2}{|c|}{ 忌 } & \multicolumn{2}{|c|}{ 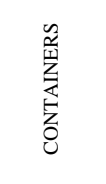 } & \multicolumn{2}{|c|}{ 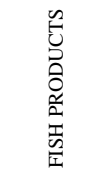 } & \multicolumn{2}{|l|}{ 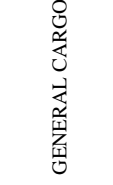 } & \multicolumn{2}{|l|}{$\overrightarrow{0}$} & \multicolumn{2}{|c|}{ 밍 } & \multicolumn{2}{|c|}{ 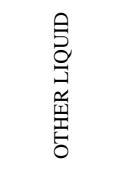 } & \multicolumn{2}{|c|}{ 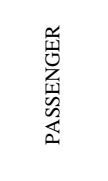 } & 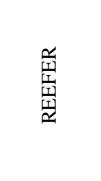 & \multicolumn{2}{|l|}{$\begin{array}{l}0 \\
\frac{4}{1} \\
\text { \& }\end{array}$} & \multicolumn{2}{|c|}{ 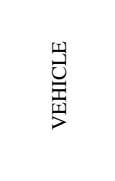 } & $\begin{array}{l}\text { ठิ } \\
\vdots\end{array}$ & \multirow[t]{2}{*}{ 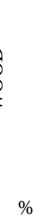 } \\
\hline & & DWT & $\%$ & DWT & $\%$ & DWT & $\%$ & DWT & $\%$ & DWT & $\%$ & DWT & $\%$ & DWT & $\%$ & DWT & $\%$ & DWT & $\%$ & DWT & $\%$ & DWT $\%$ & DWT & $\%$ & DWT & $\%$ & DWT & \\
\hline \multirow{3}{*}{ Cheongjin } & $85-91$ & 892.9 & 13.6 & 0.0 & 0.0 & 1.7 & 0.7 & 54.4 & 26.5 & 0.0 & 0.0 & 3384.0 & 22.5 & 2.1 & 0.2 & 34.0 & 3.1 & 199.5 & 15.0 & 0.0 & 0.0 & 8.37 .2 & 13.81 & 14.3 & 15.4 & 27.1 & 0.0 & 0.0 \\
\hline & $92-99$ & 932.3 & 14.4 & 0.0 & 0.0 & 0.0 & 0.0 & 18.2 & 9.9 & 1.5 & 9.1 & 1331.2 & 15.7 & 76.6 & 5.2 & 0.0 & 0.0 & 0.0 & 0.0 & 10.7 & 7.1 & 49.939 .4 & 15.8 & 8.6 & 24.8 & 40.7 & 0.0 & 0.0 \\
\hline & $00-06$ & 505.0 & 9.9 & 4.1 & 6.7 & 44.4 & & 32.1 & 39.0 & 1.7 & 3.6 & 892.3 & 13.5 & 26.2 & 1.4 & & 100.0 & 256.3 & 32.5 & 6.4 & 6.5 & $3.9 \quad 2.6$ & 0.0 & 0.0 & 0.0 & 0.0 & 0.0 & 0.0 \\
\hline \multirow{3}{*}{ Haeju } & $85-91$ & 29.5 & 0.4 & 0.0 & 0.0 & 0.0 & 0.0 & 0.0 & 0.0 & 0.0 & 0.0 & 201.5 & 1.3 & 0.0 & 0.0 & 0.0 & 0.0 & 0.0 & 0.0 & 0.0 & 0.0 & $\begin{array}{ll}0.0 & 0.0\end{array}$ & 0.0 & 0.0 & 0.0 & 0.0 & 0.0 & 0.0 \\
\hline & $92-99$ & 22.2 & 0.3 & 0.0 & 0.0 & 0.0 & 0.0 & 0.0 & 0.0 & 2.8 & 16.9 & 413.9 & 4.9 & 0.0 & 0.0 & 0.0 & 0.0 & 0.0 & 0.0 & 0.0 & 0.0 & 5.54 .4 & 0.0 & 0.0 & 0.0 & 0.0 & 44.1 & 48.3 \\
\hline & 00-06 & 37.2 & 0.7 & 0.0 & 0.0 & 0.0 & 0.0 & 0.0 & 0.0 & 9.2 & 19.3 & 499.9 & 7.5 & 286.21 & 14.9 & 0.0 & 0.0 & 0.0 & 0.0 & 0.0 & 0.0 & 24.016 .1 & 0.0 & 0.0 & 0.0 & 0.0 & 0.0 & 0.0 \\
\hline \multirow{3}{*}{ Heungnam } & $85-91$ & 1371.5 & 20.9 & 0.0 & 0.0 & 0.0 & 0.0 & 50.8 & 24.8 & 11.2 & 81.3 & 2850.0 & 19.0 & 60.6 & 4.9 & 34.0 & 3.1 & 0.0 & 0.0 & 0.0 & 0.0 & 11.710 .1 & 0.0 & 0.0 & 2.2 & 3.8 & 0.0 & 0.0 \\
\hline & 192-99 & 602.0 & 9.3 & 8.2 & 18.2 & 4.6 & 3.5 & 21.4 & 11.6 & 1.5 & 9.1 & 592.1 & 7.0 & 102.7 & 6.9 & 0.0 & 0.0 & 96.0 & 39.5 & 2.0 & 1.3 & 14.611 .6 & 14.8 & 8.1 & 4.2 & 6.8 & 23.6 & 25.9 \\
\hline & 00-06 & 425.1 & 8.3 & 0.0 & 0.0 & 0.0 & 0.0 & 0.0 & 0.0 & 1.5 & 3.2 & 539.3 & 8.1 & 0.0 & 0.0 & 0.0 & 0.0 & 38.4 & 4.9 & 0.0 & 0.0 & $11.1 \quad 7.4$ & 48.62 & 26.5 & 42.6 & 45.9 & 401.6 & 94.4 \\
\hline \multirow{3}{*}{ Nampo } & 85-91 & 2814.4 & 42.9 & 219.71 & 100.0 & 53.4 & 23.0 & & 19.0 & 0.4 & 3.2 & 4202.8 & 28.0 & 19.4 & 1.6 & 864.9 & 78.2 & 140.0 & 10.5 & 1.3 & 100.0 & 31.026 .7 & 47.94 & 49.6 & 39.2 & 69.1 & 0.0 & 0.0 \\
\hline & 92-99 & 3365.9 & 52.0 & 36.8 & 81.8 & 26.0 & & 103.4 & 56.0 & 0.0 & 0.0 & 3818.1 & 45.1 & 418.52 & & 154.7 & 80.6 & 25.6 & 10.5 & 0.0 & 0.0 & 24.119 .0 & 0.0 & 0.0 & 19.1 & 31.3 & 23.6 & 25.9 \\
\hline & 00-06 & 2743.7 & 53.9 & 45.0 & 73.3 & 5.1 & 3.3 & 25.3 & 30.7 & 6.2 & 12.9 & 3443.4 & 52.0 & 434.02 & & 0.0 & 0.0 & 179.0 & 22.7 & 0.0 & 0.0 & 12.68 .5 & 15.1 & 8.2 & 21.4 & 23.1 & 0.0 & 0.0 \\
\hline \multirow{3}{*}{ Rajin } & 85-91 & 84.3 & 1.3 & 0.0 & 0.0 & 3.0 & 1.3 & 0.0 & 0.0 & 0.0 & 0.0 & 703.3 & 4.7 & 3.0 & 0.2 & 68.1 & 6.2 & 0.0 & 0.0 & 0.0 & 0.0 & 40.735 .1 & 11.41 & 11.8 & 0.0 & 0.0 & 0.0 & 0.0 \\
\hline & 92-99 & 449.1 & 6.9 & 0.0 & 0.0 & 0.0 & 0.0 & 11.5 & 6.2 & 0.0 & 0.0 & 378.9 & 4.5 & 1.4 & 0.1 & 0.0 & 0.0 & 0.0 & 0.0 & 0.0 & 0.0 & $\begin{array}{ll}0.0 & 0.0\end{array}$ & 17.0 & 9.2 & 0.0 & 0.0 & 0.0 & 0.0 \\
\hline & 00-06 & 33.7 & 0.7 & 0.0 & 0.0 & 0.0 & 0.0 & 4.8 & 5.8 & 0.3 & 0.7 & 232.0 & 3.5 & 1.7 & 0.1 & 0.0 & 0.0 & 2.1 & 0.3 & 0.0 & 0.0 & 65.844 .2 & 0.0 & 0.0 & 0.0 & 0.0 & 23.6 & 5.6 \\
\hline & 85-91 & 77.0 & 1.2 & 0.0 & 0.0 & 0.0 & 0.0 & 0.0 & 0.0 & 0.0 & 0.0 & 9.7 & 0.1 & 0.0 & 0.0 & 0.0 & 0.0 & 0.0 & 0.0 & 0.0 & 0.0 & $\begin{array}{ll}0.0 & 0.0\end{array}$ & 0.0 & 0.0 & 0.0 & 0.0 & 0.0 & 0.0 \\
\hline Songjin & 92-99 & 0.0 & 0.0 & 0.0 & 0.0 & 0.0 & 0.0 & 0.0 & 0.0 & 0.0 & 0.0 & 22.9 & 0.3 & 12.3 & 0.8 & 0.0 & 0.0 & 0.0 & 0.0 & 0.0 & 0.0 & 18.214 .4 & 0.0 & 0.0 & 0.0 & 0.0 & 0.0 & 0.0 \\
\hline & 00-06 & 54.5 & 1.1 & 8.2 & 13.3 & 12.2 & 7.8 & 8.1 & 9.9 & 0.0 & 0.0 & 201.1 & 3.0 & 94.8 & 4.9 & 0.0 & 0.0 & 91.0 & 11.5 & 0.0 & 0.0 & $\begin{array}{ll}1.2 & 0.8\end{array}$ & 0.0 & 0.0 & 0.0 & 0.0 & 0.0 & 0.0 \\
\hline & 85-91 & 0.0 & 0.0 & 0.0 & 0.0 & 0.0 & 0.0 & 0.0 & 0.0 & 0.0 & 0.0 & 0.0 & 0.0 & 5.9 & 0.5 & 0.0 & 0.0 & 0.0 & 0.0 & 0.0 & 0.0 & $\begin{array}{ll}0.0 & 0.0\end{array}$ & 0.0 & 0.0 & 0.0 & 0.0 & 0.0 & 0.0 \\
\hline Songrim & 92-99 & 0.0 & 0.0 & 0.0 & 0.0 & 0.0 & 0.0 & 0.0 & 0.0 & 0.0 & 0.0 & 16.3 & 0.2 & 0.0 & 0.0 & 0.0 & 0.0 & 0.0 & 0.0 & 0.0 & 0.0 & $\begin{array}{ll}0.0 & 0.0\end{array}$ & 0.0 & 0.0 & 12.9 & 21.2 & 0.0 & 0.0 \\
\hline & 00-06 & 0.0 & 0.0 & 0.0 & 0.0 & 3.4 & 2.1 & 0.0 & 0.0 & 0.5 & 1.1 & 12.1 & 0.2 & 8.4 & 0.4 & 0.0 & 0.0 & 30.0 & 3.8 & 0.0 & 0.0 & $\begin{array}{lll}0.0 & 0.0 \\
\end{array}$ & 10.5 & 5.7 & 28.7 & 31.0 & 0.0 & 0.0 \\
\hline & 85-91 & 592.6 & 9.0 & 0.0 & 0.0 & 164.4 & 70.7 & 20.1 & 9.8 & 1.8 & 13.3 & 2043.6 & 13.6 & 1119.79 & 90.4 & 8.7 & 0.8 & 985.8 & 74.3 & 0.0 & 0.0 & $\begin{array}{ll}0.0 & 0.0\end{array}$ & 0.0 & 0.0 & 0.0 & 0.0 & 0.0 & 0.0 \\
\hline Wonsan & $92-99$ & 68.2 & 1.1 & 0.0 & 0.0 & 49.7 & 37.6 & 0.0 & 0.0 & 9.3 & 56.1 & 897.7 & 10.6 & 352.22 & & 0.0 & 0.0 & 0.0 & 0.0 & 137.2 & 91.5 & 0.40 .3 & 135.97 & & 0.0 & 0.0 & 0.0 & 0.0 \\
\hline & 00-06 & 0.0 & 0.0 & 0.0 & 0.0 & 22.8 & 14.6 & 0.0 & 0.0 & 25.8 & 54.1 & 343.8 & 5.2 & 106.2 & 5.5 & 0.0 & 0.0 & 4.9 & 0.6 & 90.6 & 92.4 & 11.47 .7 & 90.64 & 49.3 & 0.0 & 0.0 & 0.0 & 0.0 \\
\hline
\end{tabular}

Source: Lloyd's Marine Intelligence Unit

* percentages refer to the share of traffics in North Korea's total

Table 8: Growth rates of bulk and general cargo traffics at North Korean ports (Unit: \%)

\begin{tabular}{lrcrrrr}
\hline \multicolumn{3}{c}{ Port city } & \multicolumn{3}{c}{ Bulk } & \multicolumn{4}{c}{ General cargo } \\
\hline & $(85-91) /$ & $(92-99) /$ & $(85-91) /$ & $(85-91) /$ & $(92-99) /$ & $(85-91) /$ \\
Cheongjin & $(92-99)$ & $(00-06)$ & $(00-06)$ & $(92-99)$ & $(00-06)$ & $(00-06)$ \\
Haeju & $\mathbf{+ 4 . 4}$ & -45.8 & -43.4 & -60.7 & -33.0 & -73.6 \\
Heungnam & -24.9 & $\mathbf{+ 6 8 . 0}$ & $\mathbf{+ 2 6 . 2}$ & $\mathbf{+ 1 0 5 . 4}$ & $\mathbf{+ 2 0 . 8}$ & $\mathbf{+ 1 4 8 . 1}$ \\
Nampo & -56.1 & -29.4 & -69.0 & -79.2 & -8.9 & -81.1 \\
Rajin & $\mathbf{+ 1 9 . 6}$ & -18.5 & -2.5 & -9.2 & -9.8 & -18.1 \\
Songjin & $\mathbf{+ 4 3 2 . 7}$ & -92.5 & -60.1 & -46.1 & -38.8 & -67.0 \\
Songrim & -100.0 & & -29.2 & $\mathbf{+ 1 3 7 . 6}$ & $\mathbf{+ 7 7 6 . 9}$ & $\mathbf{+ 1 9 8 3 . 4}$ \\
Wonsan & & & & & -25.9 & \\
Total & -88.5 & -100.0 & -100.0 & -56.1 & -61.7 & -83.2 \\
\hline Sota & -1.5 & -21.3 & -22.5 & -43.7 & -21.7 & -55.9 \\
\hline
\end{tabular}

Source: Lloyd's Marine Intelligence Unit 
Figure 1: Evolution of regional and urban population in North Korea
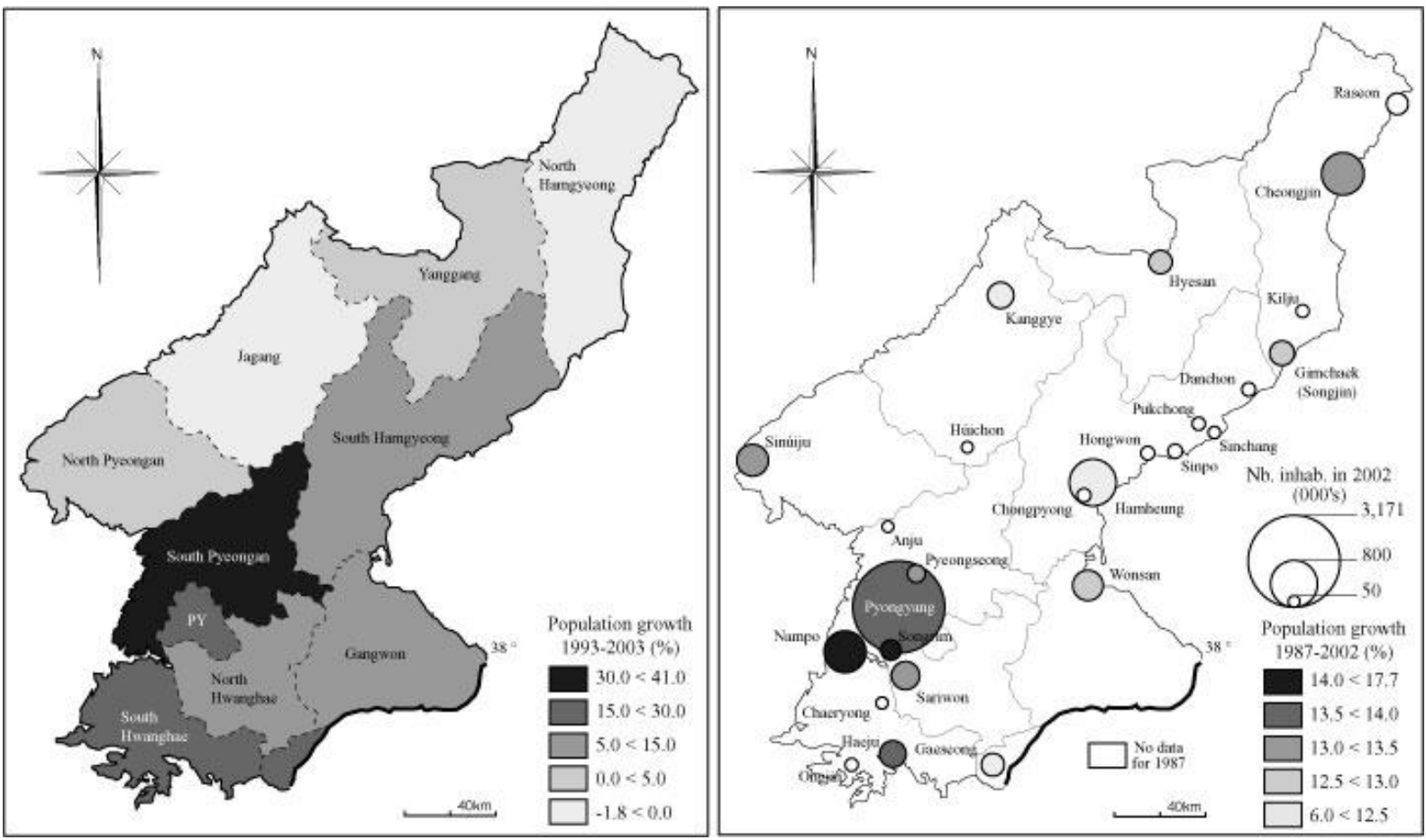

Sources: Jo \& Adler, 2002; World Gazeetter, 2006 
Figure 2: Current development projects in North Korea

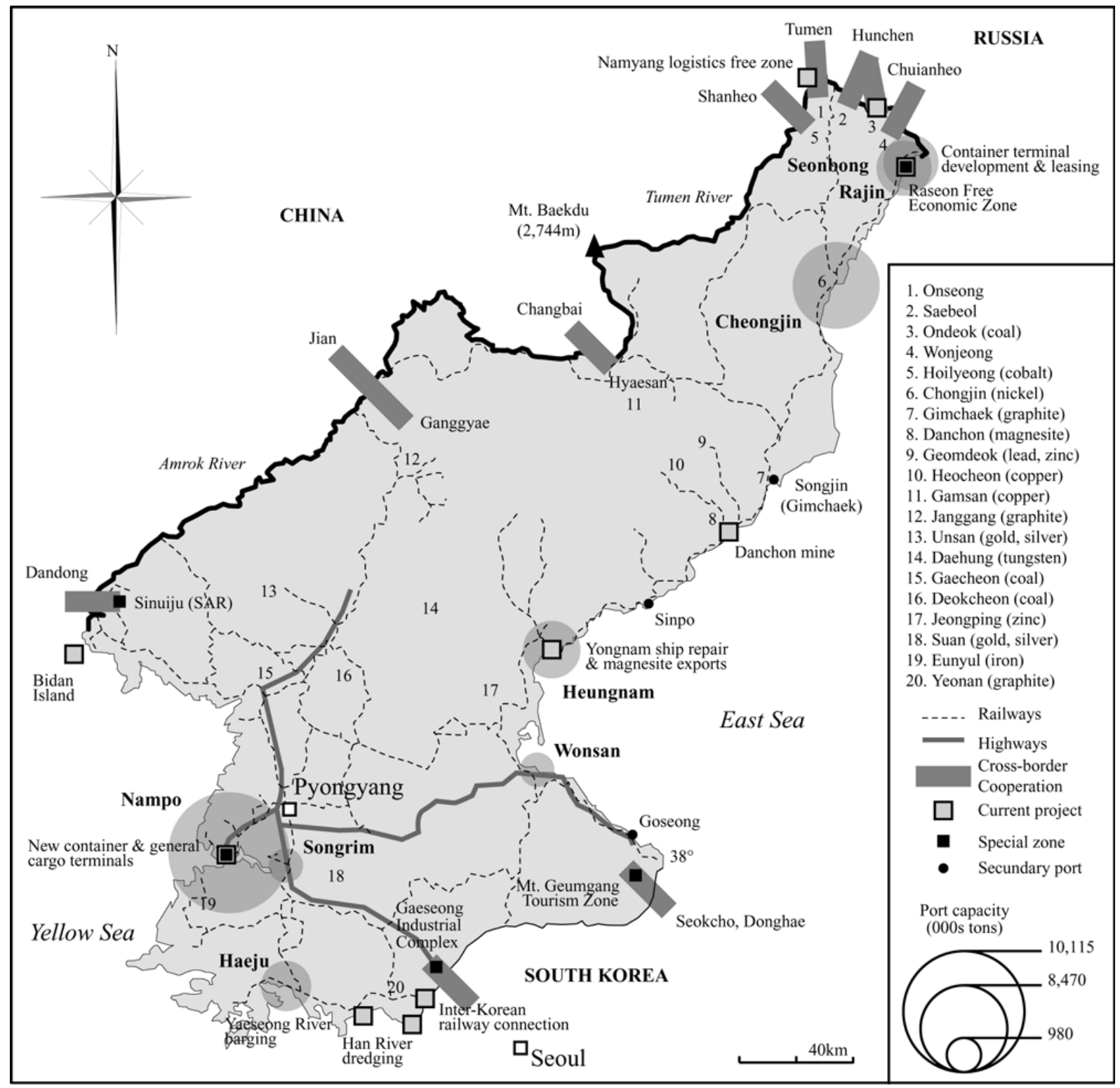

Source: compiled from various sources 
Figure 3: Evolution of total North Korean trade and shipping capacity, 1985-2005

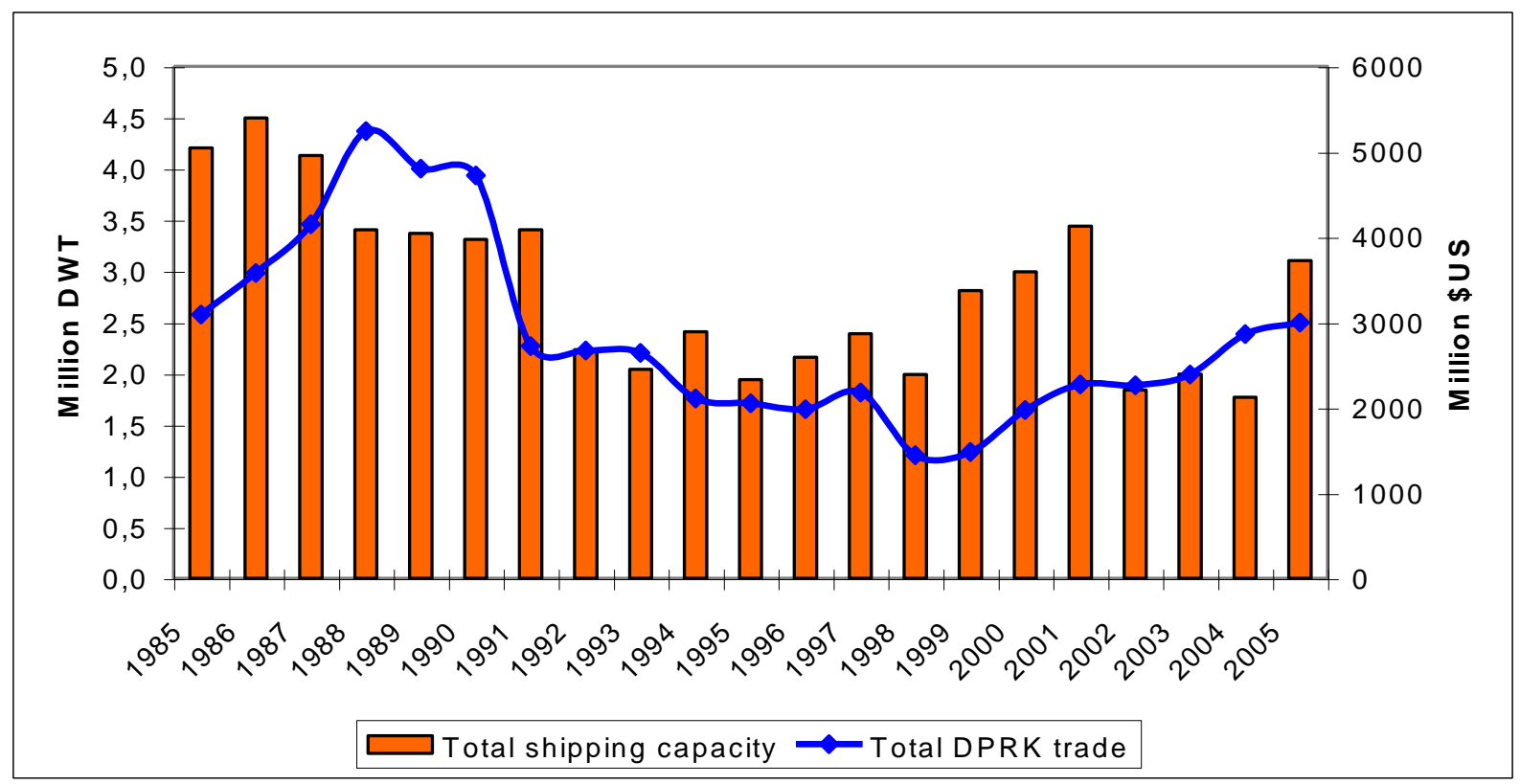

Sources: Lloyd's Marine Intelligence Unit; Korea Trade and Investment Promotion Agency

Figure 4: Estimated share of sea transport in North Korean trade, 1985-2005 (Unit: \%\$US)

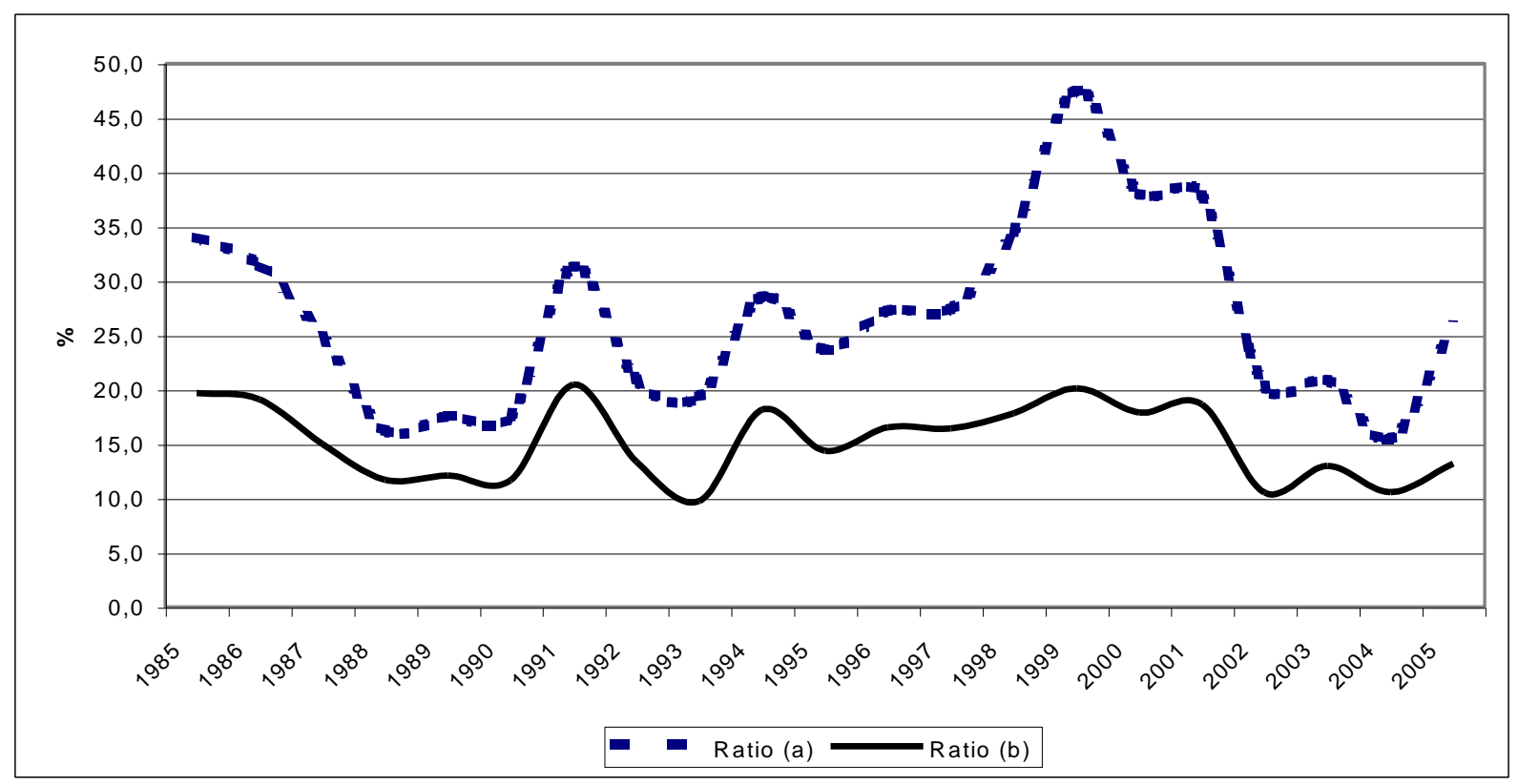

Sources: Lloyd's Marine Intelligence Unit; Korea Trade and Investment Promotion Agency 
Figure 5: Evolution of the North Korean port system, 1985-2006 (Unit: \%DWT)

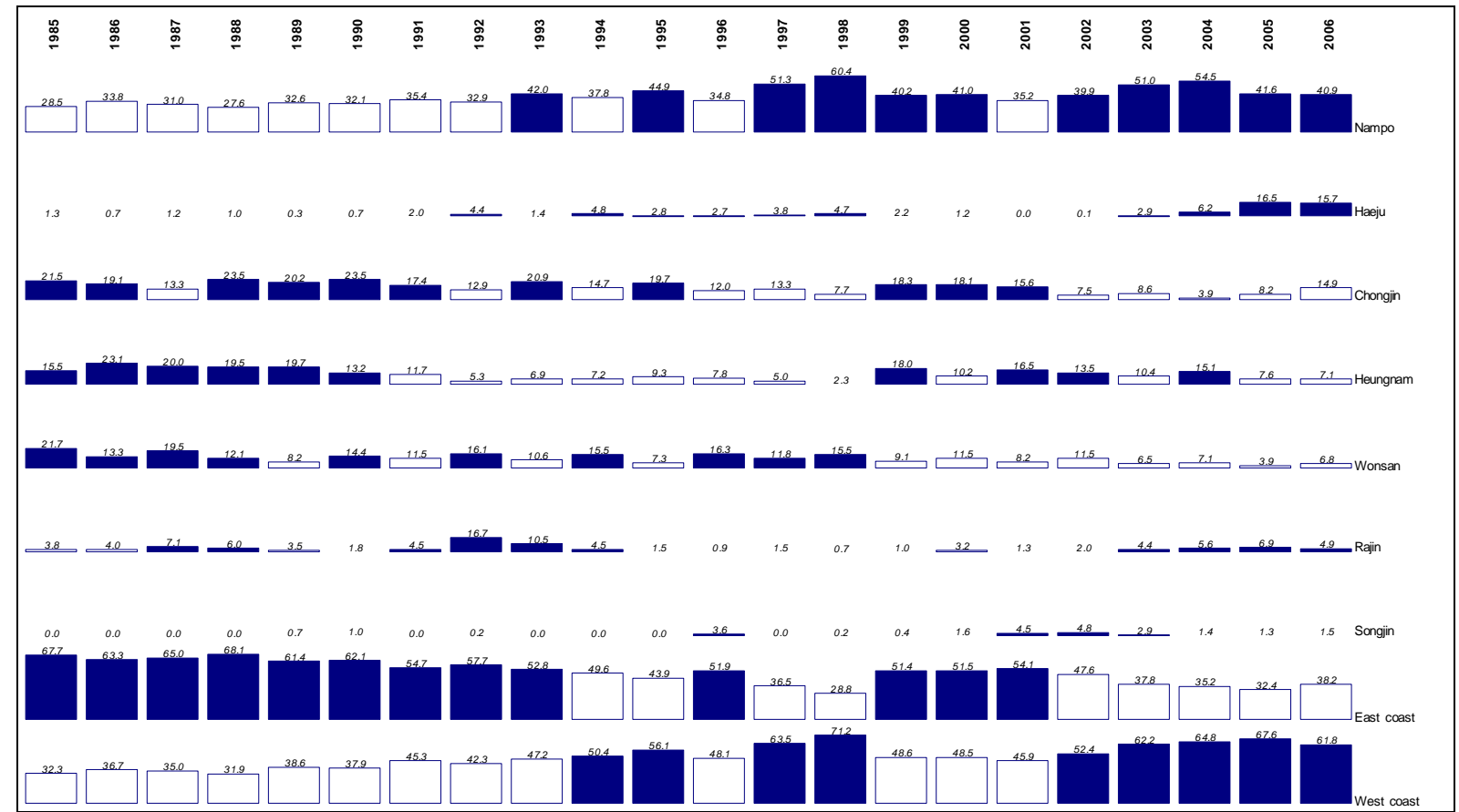

Source: Lloyd's Marine Intelligence Unit
(a) Figures for 2006 are available until August
(b) Percentages refer to the share of weighted tons
(c) Dark colours are above the average of the row 